(i)

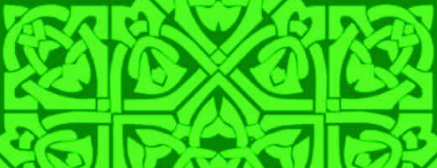

$4(5)$ a

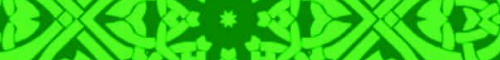

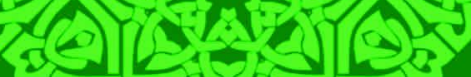

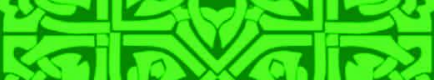

(i)

सहा

400

(a)

(4)

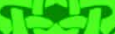

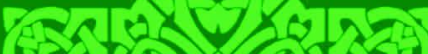

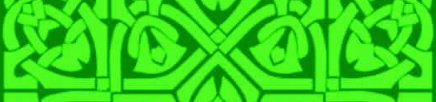

2

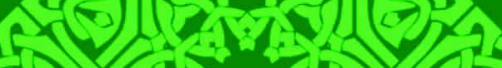

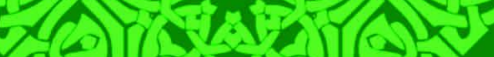

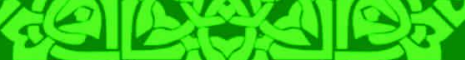

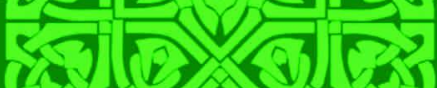

Gel

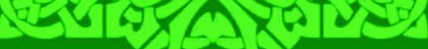

40

$\checkmark$

(क)

20?

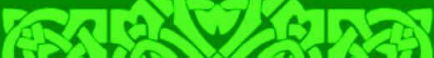

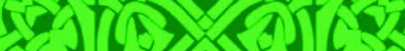

$+2$

tर
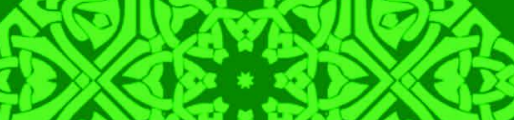

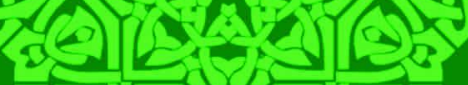

रत्र कि 02

cas as

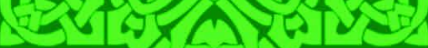

60

w

Vol 19. No $1 / 2019$
Rabiatul Adawiah, Srimusdikawati Contextualization And Entextualization Mandarese Patriotism In Kalindaqdaq Pettomuaneang Performance

Mahmuddin دراسة لغوية عن المجاز و علاقته في فهم التعاليم الدينية

Andi Miswar

Semantic Analysis On The Use Of Hijab And Jilbab Based On Quran Perspective

Aksa Muhammad Nawawi أغر اض الاستفهام بـ "هل" فى الذكر الحكيم

Syamzan Syukur Endogamy Marriage Tradition Of Sayyid Community In Sidenre Village, Binamu District, Jeneponto Regency 


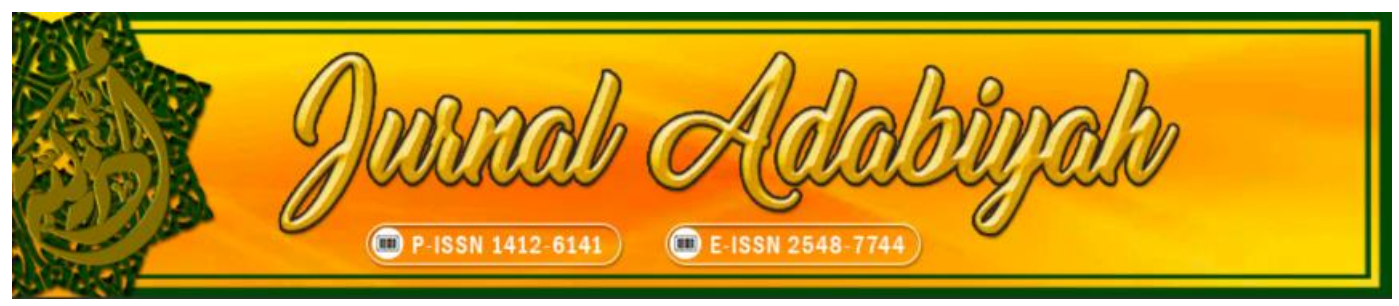

Thema: Humanities

\section{VOLUME 19 NO. 1 JUNI 2019}

\section{EDITOR-IN-CHIEF}

Barsihannor, Alauddin State Islamic University, Indonesia

INTERNATIONAL EDITORIAL BOARD

Nuri Emmiyati, Alauddin State Islamic University, Indonesia

Minako Sakai, Australian National University (ANU), Australia

Abd Rauf Muhammad Amin, Fakulti Syariah Kupu SB Brunei Darussalam, Brunei Darussalam Muhammad Widus Sempo, Universiti Sains Islam Malaysia, Malaysia

Salih Yousif Sharaf Mohamed, Al-Gazera University, Sudan Aishah Waenaha Waemamah, Academy of Islamic and Arabic Studies Princess of Naradhiwas University - Thailand, Thailand

\section{EXECUTIVE EDITOR}

Umar Thamrin, Universitas Islam Negeri Alauddin, Indonesia

\section{MANAGING EDITOR}

Zaenal Abidin, Universitas Islam Negeri Alauddin

\section{EDITORS}

Rosmah Tami, Alauddin State Islamic University, Indonesia Haniah Haniah, Alauddin State Islamic University, Indonesia Nasrum Nasrum, Alauddin State Islamic University, Indonesia Awaluddin Syamsu, Universitas Muslim Indonesia

Ahmadi Usman, UIN Syarif Hidayatullah Jakarta, Indonesia Baso Pallawagau, IAIN Parepare, Indonesia Muhammad Azwar, Universitas Islam Negeri Syarif Hidayatullah Jakarta, Indonesia

Muh. Saleh Syamsuri, Alauddin State Islamic University, Indonesia

Andi Satrianingsih, Muhammadiyah University, Indonesia

Syahruni - Junaid, Alauddin State Islamic University, Indonesia

Rabiatul Adawiah, Majene Islamic State College, West Sulawesi, Indonesia, Indonesia

Chusnul Chatimah Asmad, Universitas Islam Negeri Alauddin, Indonesia

Nur Arifin, Universitas Islam Negeri Alauddin, Indonesia

\section{IT SUPPORT}

Taufiq Mathar, Alauddin State Islamic University, Indonesia

\section{LANGUAGE ADVISOR}

Kustiwan Syarief, Alauddin State Islamic University, Indonesia Muh. Saleh Syamsuri, Alauddin State Islamic University, Indonesia

\section{COVER DESIGNER}

Nur Arifin 


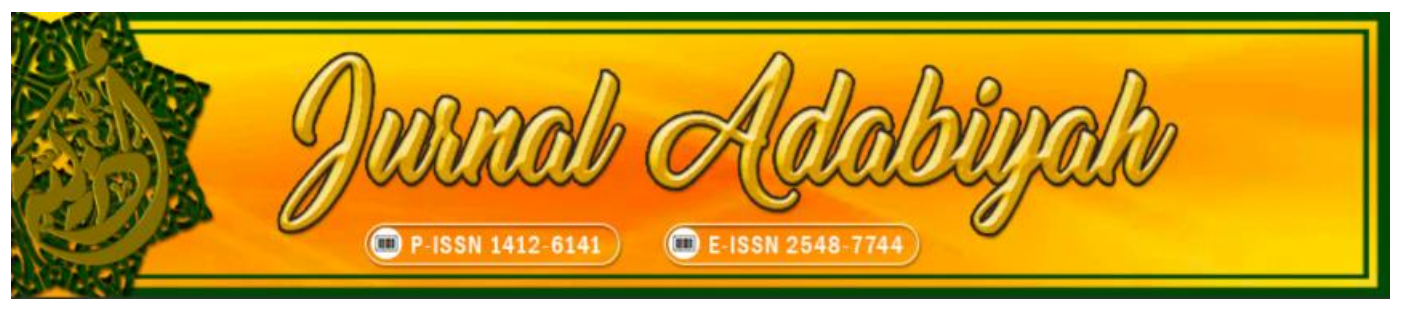

\section{Jurnal Adabiyah:}

This journal receives a national accreditation from Ministry of Research, Technology, and Higher Education Republic of Indonesia, Nomor 10/E/KPT/2019 on April 4, 2019 with the SINTA score: S2.

The Journal has been published by the Faculty of Adab and Humanity of Alauddin State Islamic University, Makassar, since 1997 and has been online since 2016 with the main themes on Humanities and Islamic Studies with the emphasis on interdisciplinary and intertextuality approach.

This journal are published twice a year, on June and December. The themes related to Islamic Studies are textual studies, scriptural traditions, Islamic law, and theology; and those related to Humanities are language, literature, history, and culture.

The journal of Humanities and Islamic Studies will provide the online collection of articles from 1997 up to now. The most updated information can be found on the website. 


\section{Table of Contents}

Rabiatul Adawiah, Srimusdikawati

Contextualization And Entextualization Mandarese Patriotism In

Kalindaqdaq Pettomuaneang Performance

Mahmuddin

در اسة لغوية عن المجاز و علاقته في فهم التعاليم الدينية

Andi Miswar

Semantic Analysis On The Use Of Hijab And Jilbab Based On Qur'an Perspective

Aksa Muhammad Nawawi

أغر اض الاستفهام بـ "هل" فى الذكر الحكيم

Syamzan Syukur, Arbianti

86-102

Endogamy Marriage Tradition Of Sayyid Community In Sidenre Village,

Binamu District, Jeneponto Regency 


\title{
دراسة لغوية عن المجاز و علاقته في فهم التعاليم الدينية
}

\author{
Mahmuddin
}

mahmuddin.harun@uin-alauddin.ac.id

Universitas Islam Negeri Alauddin

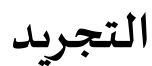

إن هذا البحث يتحدث عن كيإن المجاز كدراسة من دراسات لغوية الميات

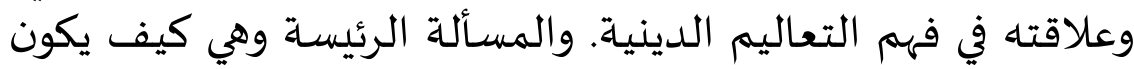

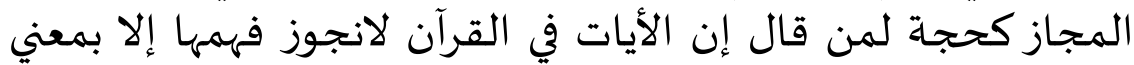

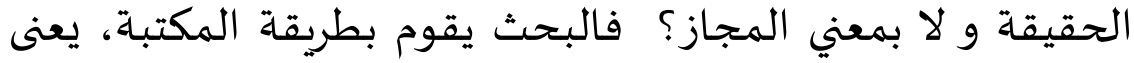

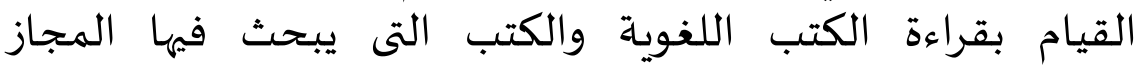

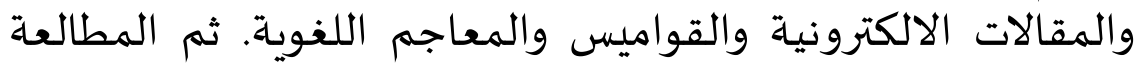

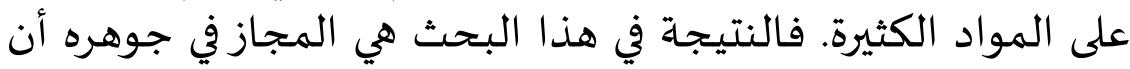

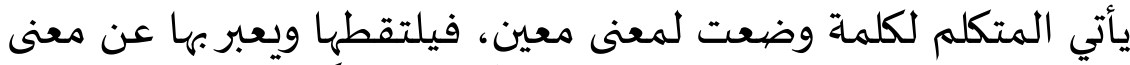

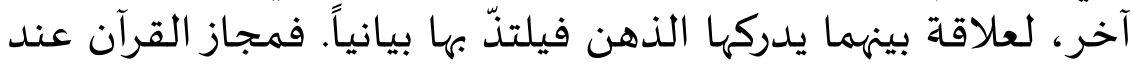

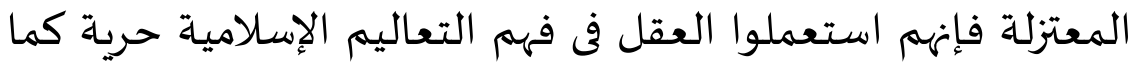

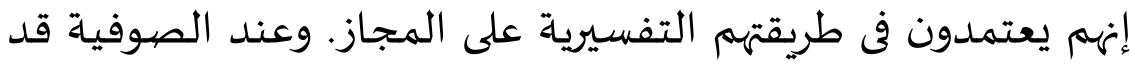

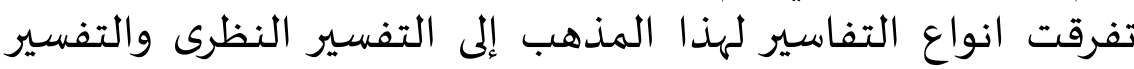

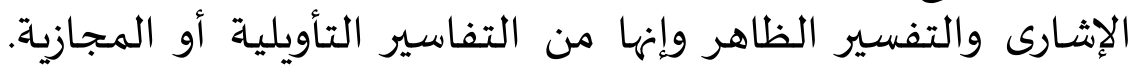

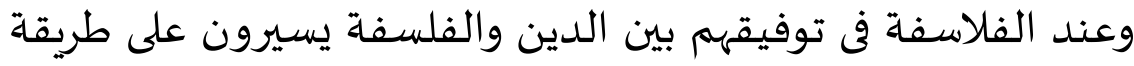

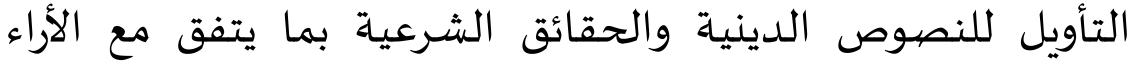

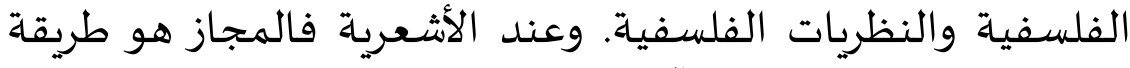

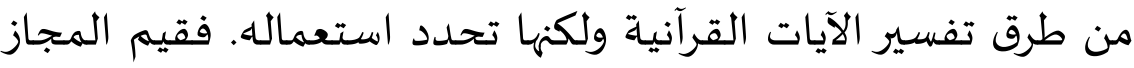

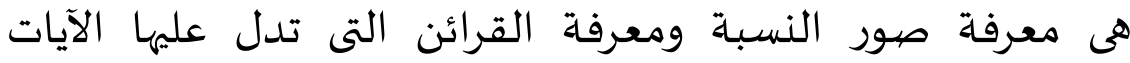

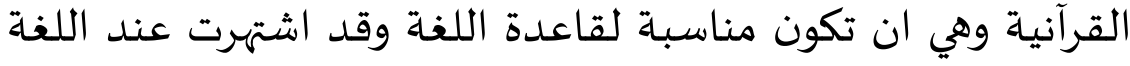

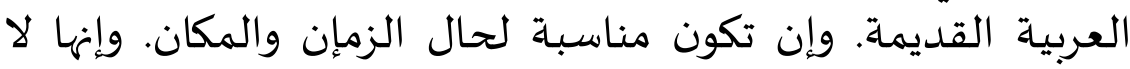
تختلف بسنة الله والتعاليم الدينية. كلمات المرور : المجاز، الحقيقة، حجة التهالة، دراسة لغوية، التعاليم 


\begin{abstract}
This research discusses about majaz and its values in the development of Islamic studies in terms of the existence of majaz as a language study and its relation to understanding the teachings of Islam. The main problem in this research is how the position of Majaz as an argument and rebuttal to those who think that actually the verses of the Qur'an cannot be understood except with the meaning of textual and cannot be understood by majaz. The research method used is a library method that is by examining books ‘ articles، dictionaries and encyclopedias related to majaz to get data. The results of this study are that the substance of majaz is a person conveying a sentence with a certain understanding then expressing it with another meaning or meaning. The Muktazilah uses the majaz in interpreting the Qur'an، while the flow of Sufism also believes in the existence of majaz in the Qur'an through its Islamic interpretation. Is the flow of philosophy also accepts majaz in understanding religious teachings. While the Asy'ariyah sect also received majaz in understanding the teachings of religion but by limiting its use. The values of majaz in Islamic studies are knowing the forms and knowing the provisions that can be guided in understanding the Qur'an by using majaz' which must be in accordance with the rules of language and in accordance with the use of Arabic sentences used during the time of the Prophet, and in accordance with the situation and conditions and the latter does not conflict with Sunnatullah and agreed religious teachings.
\end{abstract}

Keywords: majaz; values; Islamic studies; language study; understanding

\begin{abstract}
Abstrak
Penelitian ini membahas tentang majaz sebagai bagian dari studi bahasa dan hubungannya dengan pemahaman terhadap ajaran agama Islam. Penelitian ini melihat posisi majaz sebagai argumentasi dan bantahan terhadap anggapan bahwa sesungguhnya ayat-ayat al Qur'an tidak dapat difahami kecuali dengan makna hakikat (tekstual) dan tidak dapat difahami dengan majaz. Metode penelitian yang digunakan adalah metode pustaka yaitu dengan menelaah bukubuku, artikel, kamus, dan ensiklopedia yang berkaitan dengan majaz untuk mendapatkan data. Penelitian ini menemukan bahwa substansi majaz ialah seorang menyampaikan kalimat dengan pengertian tertentu lalu mengungkapkannya dengan arti atau makna yang lain. Aliran Muktazilah menggunakan majaz dalam menafsirkan al
\end{abstract}


Qur'an, sementara aliran tasawuf juga meyakini adanya majaz dalam al Qur'an melalui tafsir isyarinya. Aliran filsafat juga menerima majaz dalam memahami ajaran agama. Sementara aliran Asy'ariyah juga menerima majaz dalam memahami ajaran agama tetapi membatasi penggunaannya. Adapun nilai-nilai majaz dalam studi Islam adalah mengetahui bentuk-bentuk dan ketentuan-ketentuan yang dapat dipedomani dalam memahami al Qur'an. Penggunakan majaz harus sesuai dengan kaidah kebahasaan serta sesuai dengan penggunaan kalimat Bahasa Arab yang dipakai pada masa Nabi saw., sesuai dengan situasi dan kondisi, dan tidak bertentangan dengan sunnatullah serta ajaran-ajaran agama yang disepakati.

Kata Kunci: majaz; studi bahasa; pemahaman; ajaran agama; argumentasi; hakikat

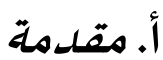

القرآن هو الكتاب المنزل إلى جميع الناس هدى لحياتهم فى الدنيا وفوزهم في الخي

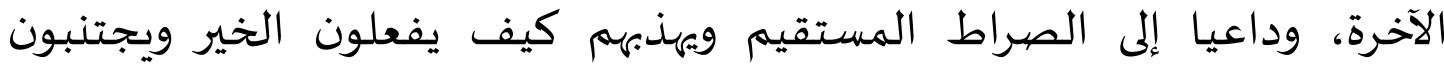

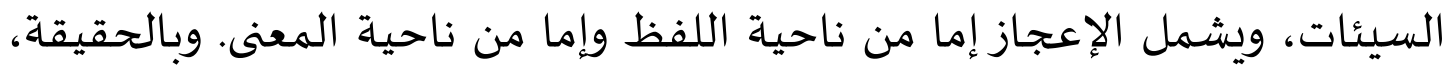

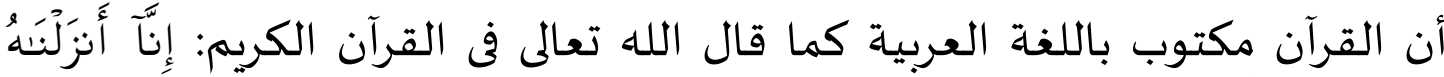

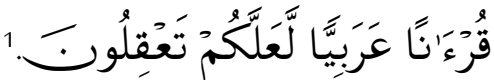

واللغة العربية لها عدة علوم منها النحو والصرف والبلاغة وغير ذلك، ومن

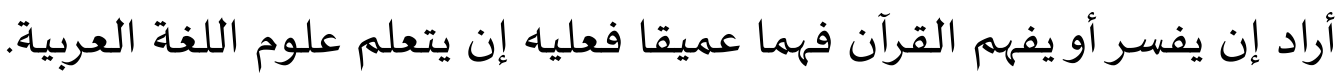

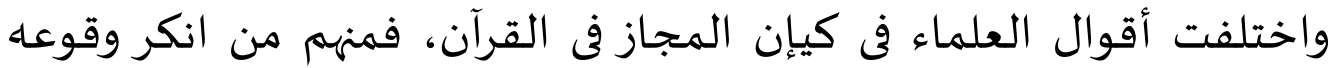

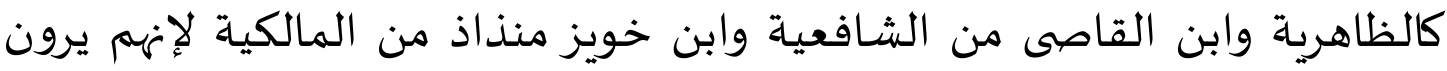
إن المجاز أخو الكذب، وكلام الله منزه عناه. فمنهم من أقر وقوعها في القرآن، مثل جمههور علماء عاء أهله أهل السنة والأشـاعرة

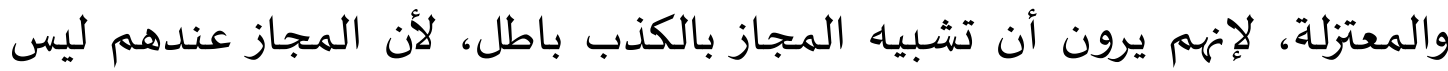

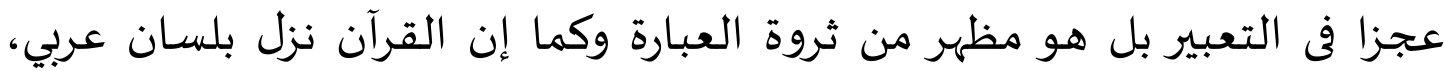
فالمجاز كنوع من فنون البلاغة. 
فمميزات علم المجاز هى إستطاعة فهم معانى القرآن المعبرة بشكل المجاز.

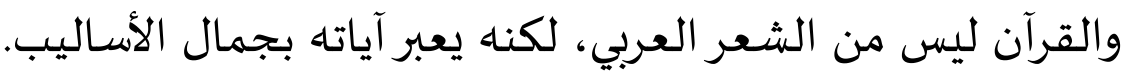

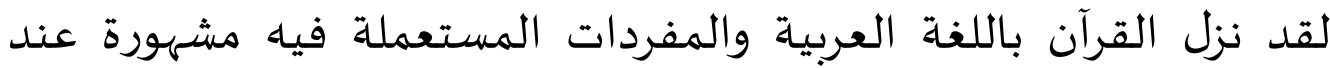

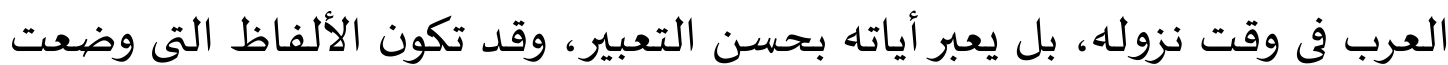

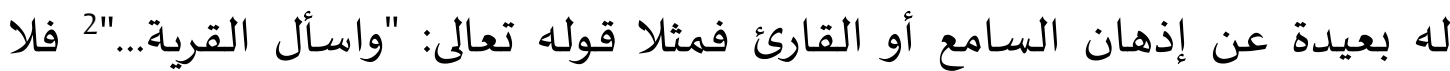

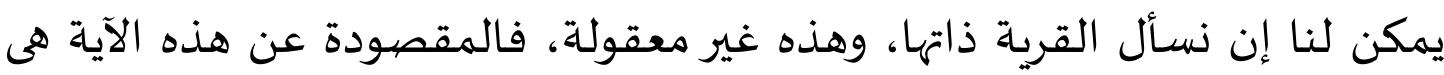

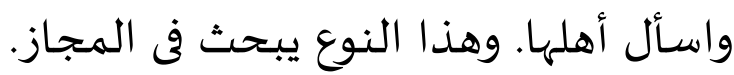

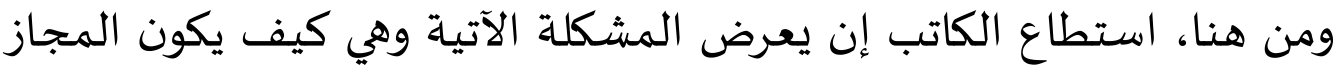

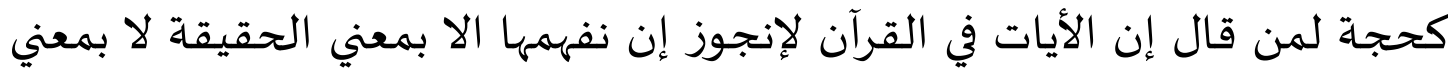

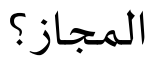

في هذا المبحث يخصص الباحث بحثـه في المجاز من حيث دراسـة لغوية.

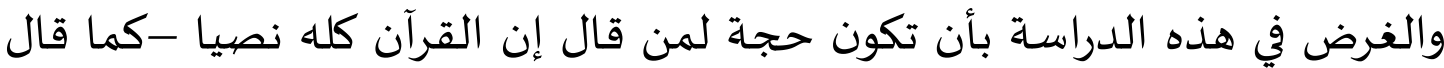

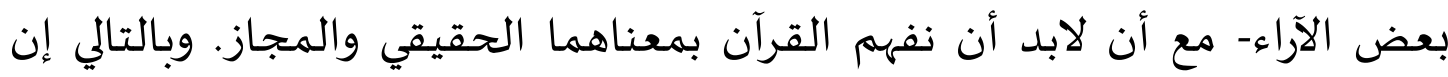

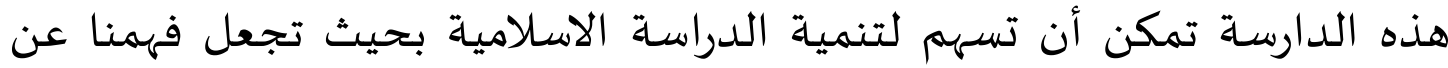

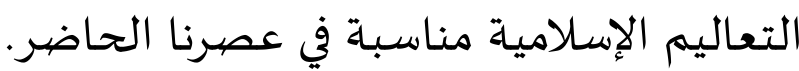

$$
\text { ب. دراسة عن المجاز في علم البيإن }
$$

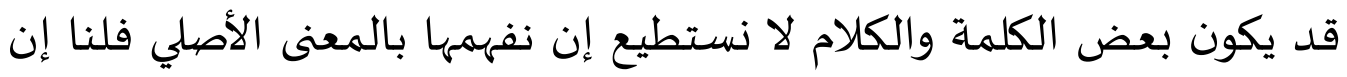

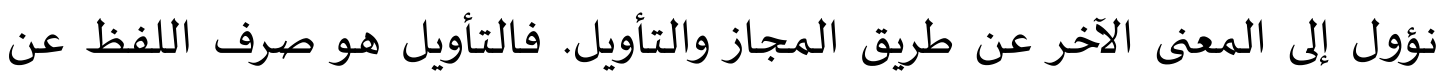

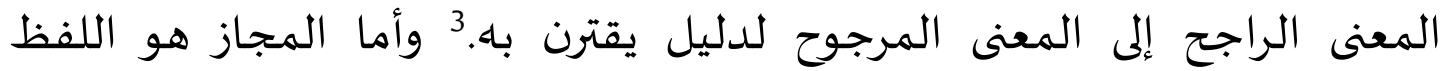

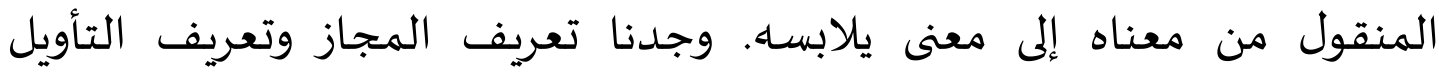
متساويين من حيث اللفظ المنقول من المعنى الظاهر إلى المعنى المؤول. معند

2الآية 82 من سورة يوسف.

3ناع القطان، مباحث فى علوم القرإن (منشور ات العصر الحديث، سنة 1393 هـ/1973 م) ص. 
وينقسم المجاز إلى قسمين هما المجاز اللغوى والمجاز العقلي. وسيأتى

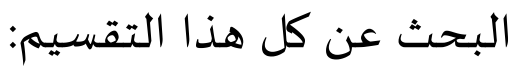

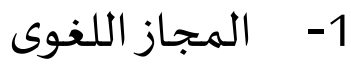

المجاز العقلي هو اللفظ المستعمل في غير ما وضع له لعلاقة مع قرينة مإنعة من إرادة المعنى الحقيقي.

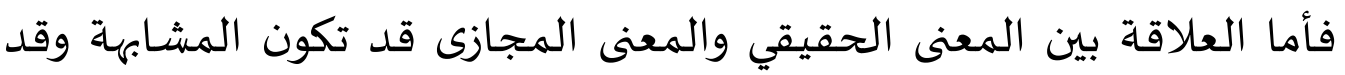

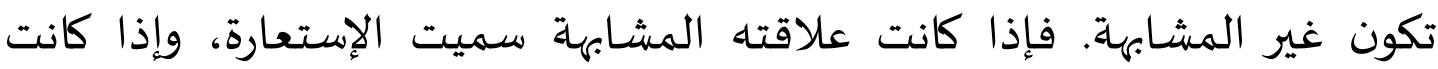

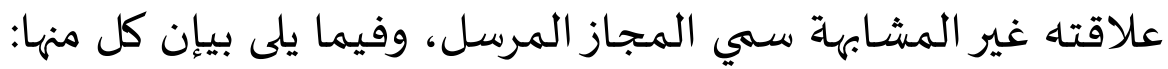

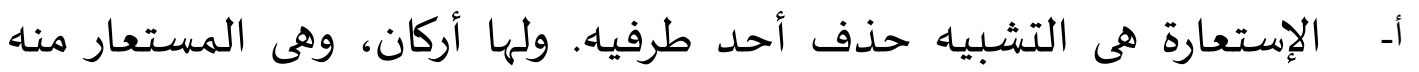

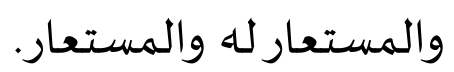

إذا كانت الإستعارة من جهار تصريح المشباه غير تصريح في الكلمة ينقسم إلى الإستعارة التصريحية والإستعارة المكنية. الإستعارة التصريحية هى ما صرح فهيها بلفظ الإنعارة المشبه بهاه، مثل:

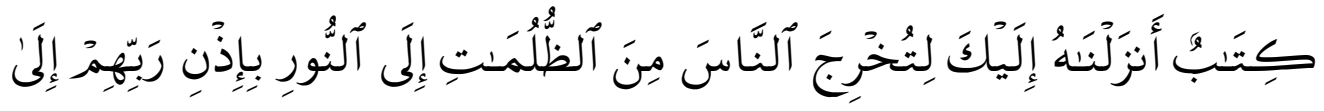

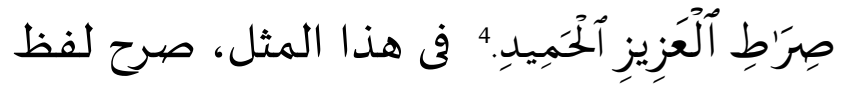
"الظلمات والنور" فياه.

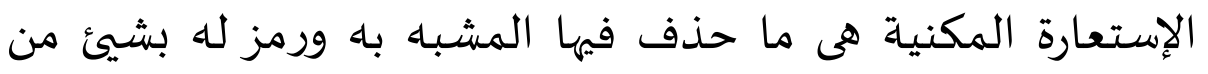

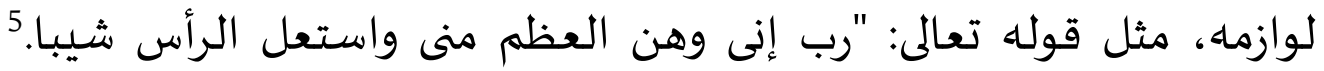

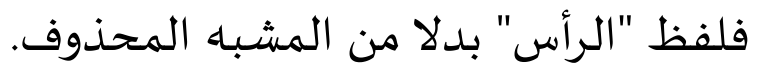
ثم إذا كانت الإستعارة من جهة الستعمال اللفظ فتوف فتكون أصلية

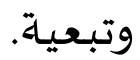


الإستعارة الأصلية هى إذا كان اللفظ المستعمل فيه إسما جامدا،

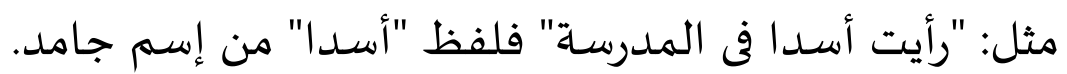

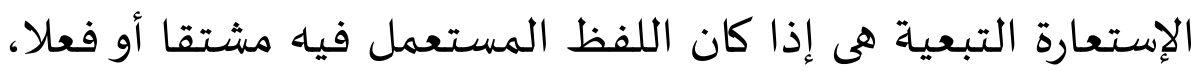

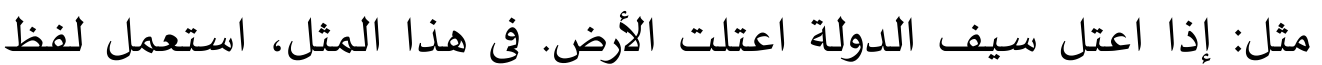

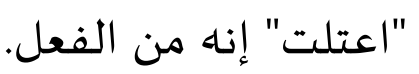

ثم إذا كانت الإستعتارة من جها الفعل الملائم تنقسم إلى المرشحة

$$
\text { والمجردة والمطلقة. }
$$

الإستعارة المرشحة هى ما ذكر فياه ملائم المشبه باه، مثل: نطق

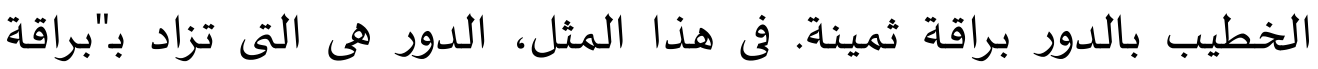

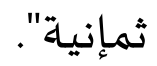
والإستعارة المجردة هى ما ذكر فياه ملائم المشباه، مثل: نطق الخطيب بالدور فارتاحت لها الإسماع.

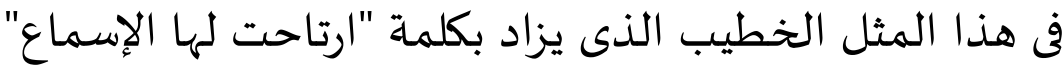

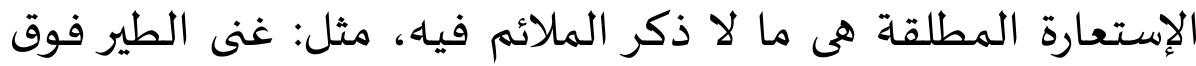

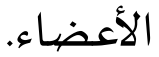

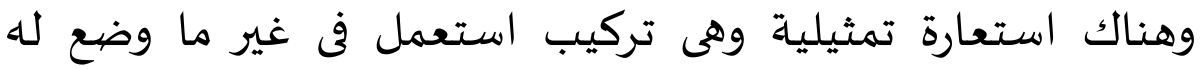

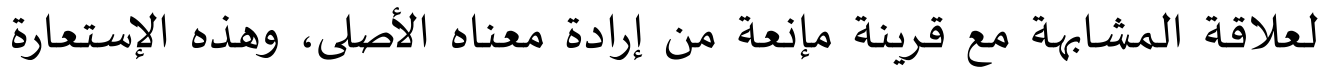

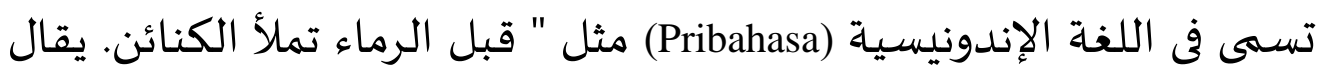

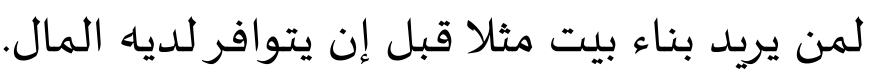

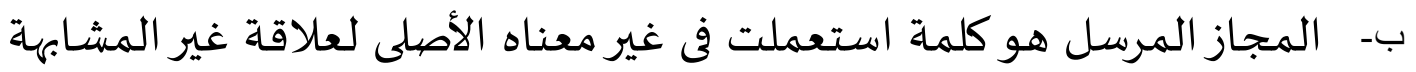

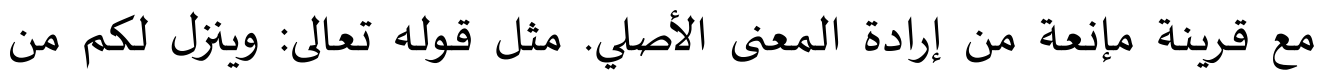

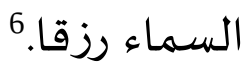

في هذه الآية لا ينزل الله الرزق مباشرة لكنه ينزل المطر حتى تنبت النبات فوق الأرض ثم تكون رزقا للابة لانس. 


$$
\begin{aligned}
& \text { المجاز المرسل لله علاقات، وهى: } \\
& \text { السببية، مثل: له أياد على لهار الهات الهات }
\end{aligned}
$$

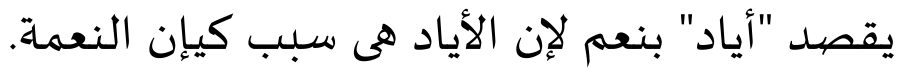

2) المسببية مثل قوله تعالى: وينزل لكم من السماء لإنياد رزقا.

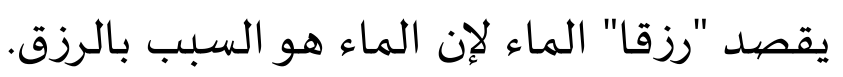

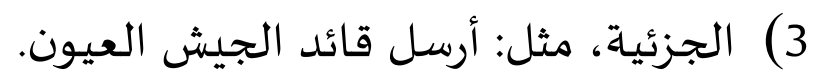

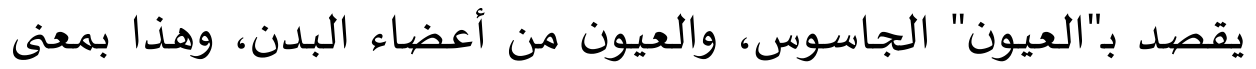

$$
\text { يذكر جزء من البدن. }
$$

4) الكلية، مثل قوله تعالى: "يجعلون أصابعهم في آذانهم".8

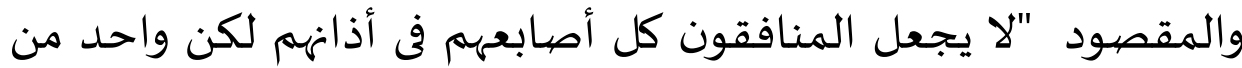

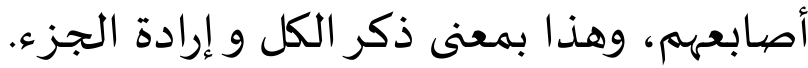
5) إعتبار ما كان، مثل: يلبس الإندونيسيون القطن إنطن.

القطن هو المادة التى يصنح منها اللباس ولكن يقصيد بالقطن اللباس.

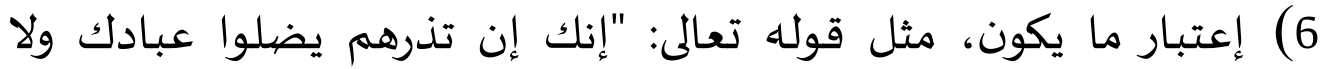

$$
\text { يلدوا فاجرا كفارا". }
$$

"فاجرا كفارا" مجازإن لإن المولود حين يولد لا يكون فاجرا ولا كفارا

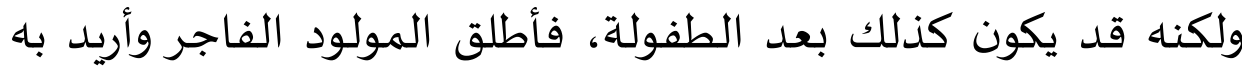
الرجل الفاجر.

المحلية، مثل قوله تعالى: "فليدع نادياء سندع الزبإبإنية". 10

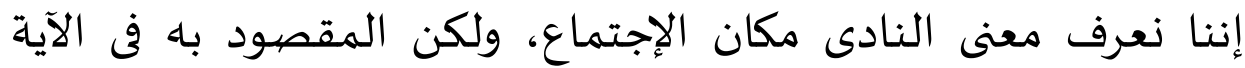
الكريمة من في هذا المكان من عشيرته، فهو مجاز أطلق فيه المحل المجل

$$
\text { وأريد الحال. }
$$

$$
\begin{aligned}
& \text { 7الآية } 13 \text { من سورة المؤمنون. } \\
& \text { 8الآية } 19 \text { من سورة البقرة. }
\end{aligned}
$$

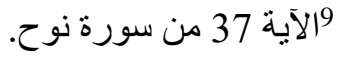

$$
\begin{aligned}
& \text { 10الآية } 17 \text { من سورة العلق. }
\end{aligned}
$$




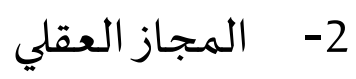

المجاز العقلى سهى أيضا بالمجاز الإسنادى هو إسناد الفعل أو ما في معناه

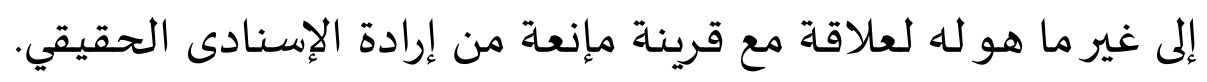

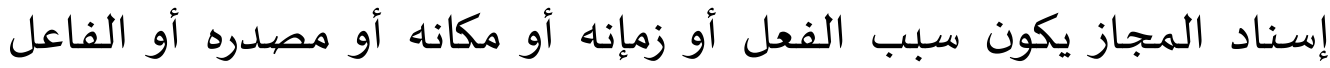

للمفعول وعكساه. وسيأتى المثال لكل الإسناد المذكور.

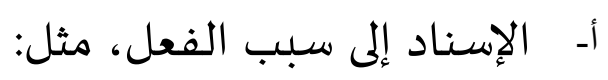

"أصلح العمدة الشوارع" لا تكون العمدة تصلح العيلح الشوارع بنفسها ولكن

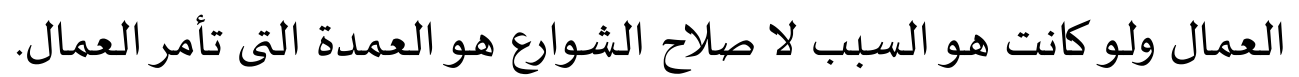

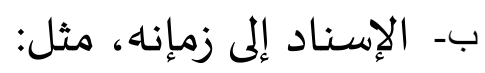

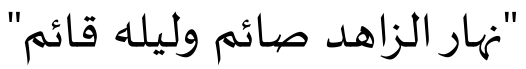

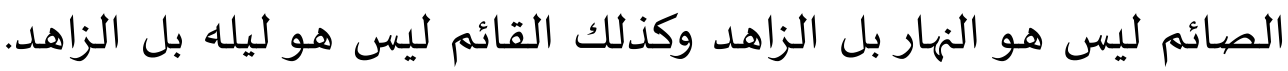

فصائم وقائم اسندا إلى زمإنهما.

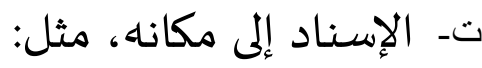

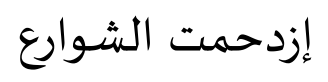

الإزدحام ليس للشوارع بل للناس، إذا هو إسناد إلى مكانه.

$$
\begin{aligned}
& \text { ثـ الإسناد إلى مصدره، مثل: } \\
& \text { "جد جده" } \\
& \text { الجد هو المرء لكن أسند إلى مصدره "جده" } \\
& \text { ج- إسناد المبنى للفاعل إلى المفعول، مثل: } \\
& \text { كان المتزل عامرا }
\end{aligned}
$$

ليس المنزل فى حقيقته "عامرا" بل "معمورا" وهذا بمعنى استعمال المبنى

$$
\text { للفاعل بدلا من المفعول. }
$$

ح- إسناد المبنى للمفعول إلى الفاعل، مثل قوله تعالى: 
"وإذا قرأت القرآن جعلنا بينك وبين الذين لا يؤمنون بالآخرة حجابا مستورا".11 - ماذ فرات الحجاب ليس مستورا بل ساترا. وكل هذا إسناد الفعل إلى غيره من اللفظ لعلاقة معاترا مع قرينة مإنعة من

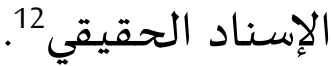

\section{ج. لمحة قصبيرة عن المجاز: أنواعه في القرآن وآراء العلماء فيه}

ذكر أنواع المجاز باعتبار علاقته يسهل علينا فهم مضيمون الكتابة فيما يلى.

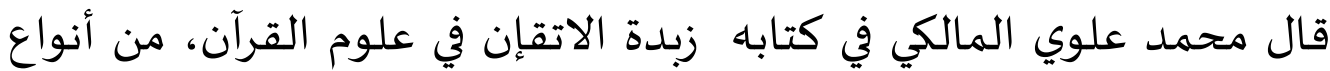

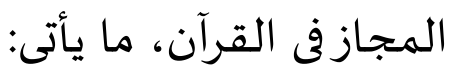

الأول : الحذف، مثل: "واسأل القرية"13 ائ واسأل أهلها.

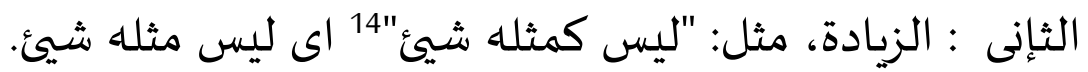

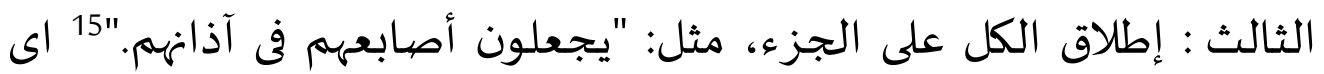

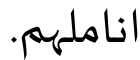
الرابع : إطلاق الجزء على الكل، مثل: "ويبقى وجها ربك". 16 اى ذاته.

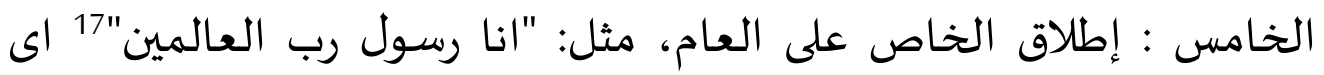
رسله.

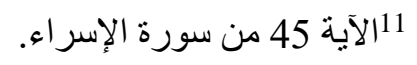

12 12 على الجارم مصطفى أمين، البلاغة الو اضحة، لندن، شركة مكملإن، الطبعة الخامسة عشرة، سنة 1961 1961 13 الآية 82 من سورة يوسف.

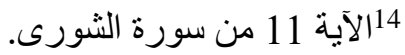

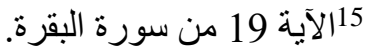

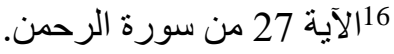
17 - الآية 16 من سورة الثعراء. 
السادس : إطلاق العام على الخاص، مثل: "ويستغفرون لمن في الأرض".18

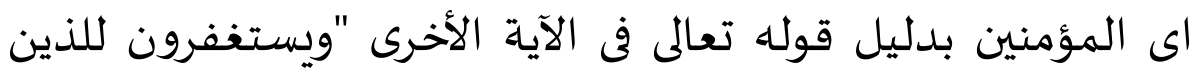
آمنوا". 19

السابع: تسمية الشيئ باسم ما كان عليه، مثل: "وآتوا اليتامى أموالهه".20 اي الذين كانوا يتامى إذ لا يتيم بعد البلوغ.

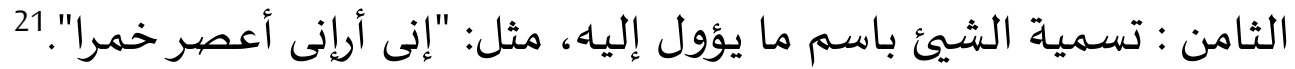

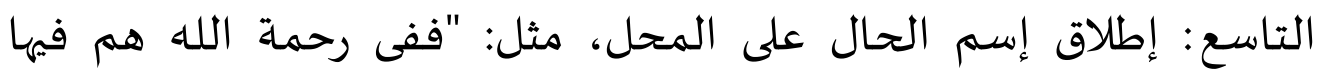
خالدون".22 اى فى الجنة لإن محل الرحمة في الجناة.

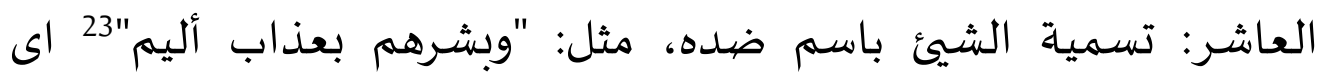

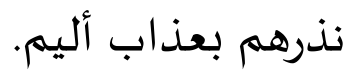

الحادى عشر: تسمية الشيئ باسم آلته، مثل: "واجعل لى لسإن صدق لدق في

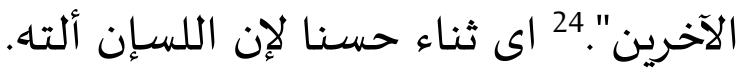

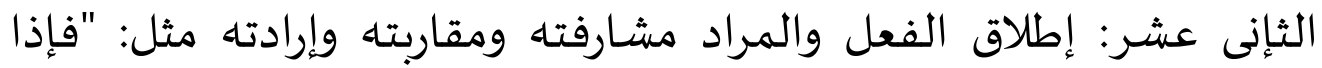

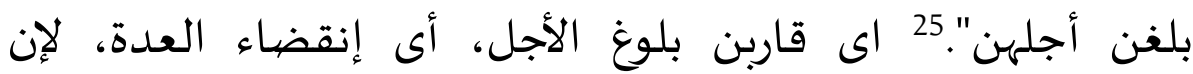
الإمساك لا يكون بعده. ومثال آخر، "وإذا قرأت القرآن فاستعذ".

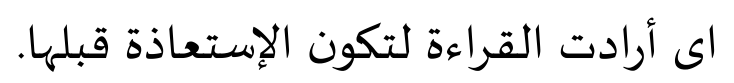
الثالث عشر: إقامة صيغة مقام أخرى، ولها انواع كثيرة منها: 18 الآية 5 من سورة الثورى. 19 الآية 7 من سورة المؤمنون. 20 الآية 2 من سورة النار. 21الآية 36 من سورة يوسف. سن سوره 222 الآية 107 من سورة آل عمر إن. 2323 - الآية 34 من سورة التوبة. 24الآية 84 من سورة الشعر اء. 25 - 25 الآية 234 من سورة البقرة. 26 الآية 98 من سورة النحل. 
أحدها : إطلاف فاعل على مفعول، مثل: "لا عاصم اليوم من أمر الله

$$
\text { إلا من رحم". }
$$

ثإنيها : إطلاق مفعول على فاعل، مثل: "إنه كان وعده مأتيا". 28 اي إي

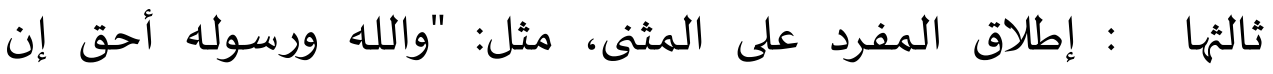

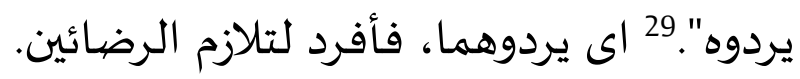

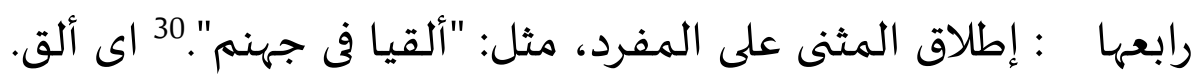

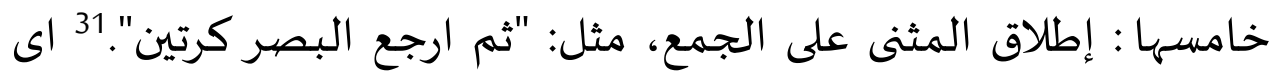
كرات لإن البصر لا يحسر إلإ بها.

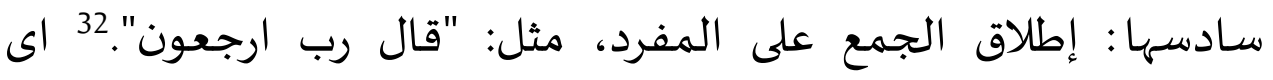

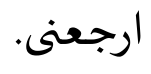

سابعها : إطلاق الماضى على المستقبل لتحقيق وقوعاء، مثل: "أتى أمر

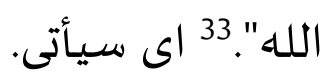

ثامنها : إطلاق المستقبل على الماضى لإفادة الدوام والإستمرار فكانه

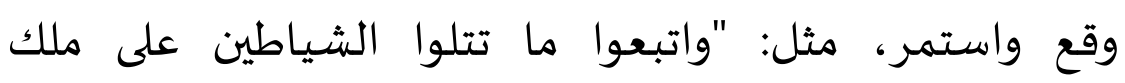

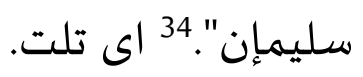

$$
\text { 29 27 الآية } 43 \text { من سورة هود. } 61 \text { من سورة مريحة. } 62 \text { من سورة التوبة. }
$$$$
\text { 30 الآية } 24 \text { من سورة ق من سورة }
$$

31/آلية 4 من سورة الملك.

$$
\text { 32الآية } 99 \text { من سورة المؤمنون. }
$$

33 الآية 1 من سورة النحل.

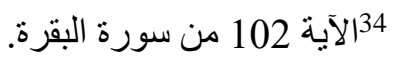


تاسعها : نسبة الفعل إلى شيئين وهو لأحدهما فقط، مثل: "يخرج منهما

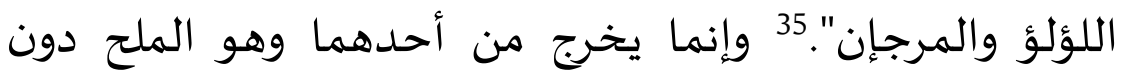

$$
\text { العذب. }
$$

وهذه هى إنواع المجاز فى القرآن الكريم التى قد ذكرها الباحث مع الأمثلة لكل هذه الإنواع.

وقد اختلفت آراء العلماء في مجاز القرآن فمنهم من انكروه ومنهم من أقروا

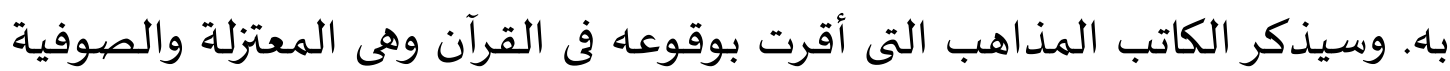

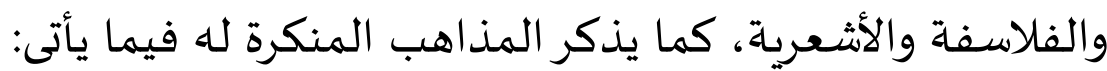

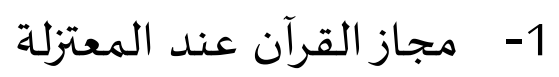

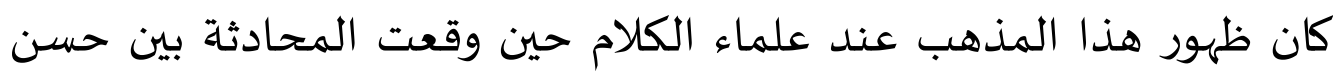
البصرى وواصل بن عطاء فى مسألة من يفعل الكبائر هل هو مؤمن او كافر، فئل فئال

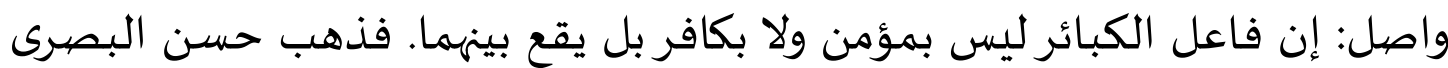

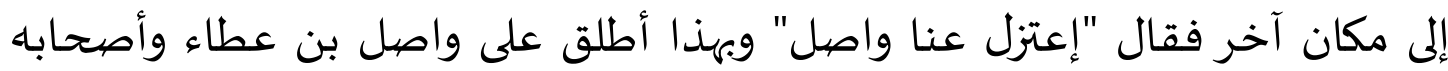

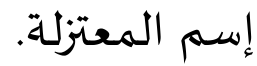

من البيإن السابق، إنهم استعملت العقل في فهم التعاليم الإسلامية حرية

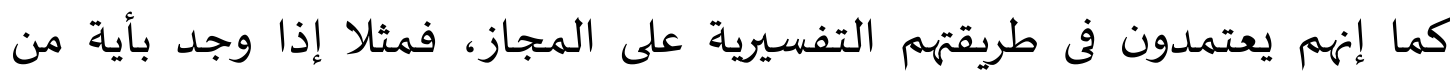
الآيات التى تبدو في ظاهرها غرببة ذهبوا إلى التمثيل أو التخييل.

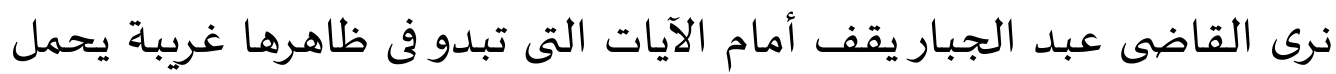
على المجازوالتشبيه. يقول في قوله تعالى "وإذ أخذ ربك من بني آدم من ظهورهم ذريتهم وأشهدهم أشهم

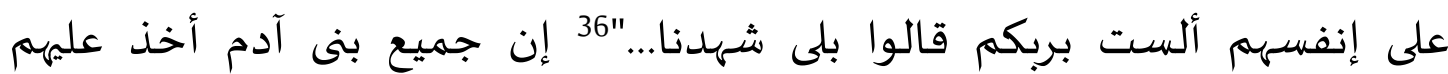

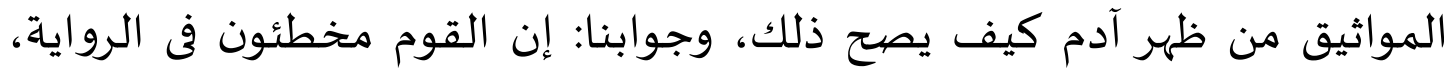

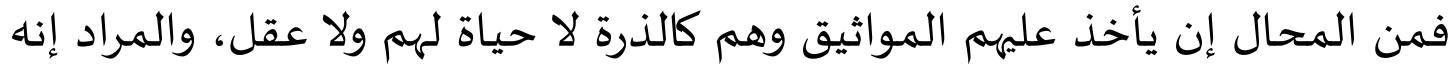

$$
\text { 36 35 الآية } 22 \text { من سورة الرحمن. } 172 \text { من سورة الأعراف. }
$$


أخذ الميثاق من العقلاء بإن أودع فى عقلهم ما ألزمهم، إذ فائدة الميثاق إن يكون

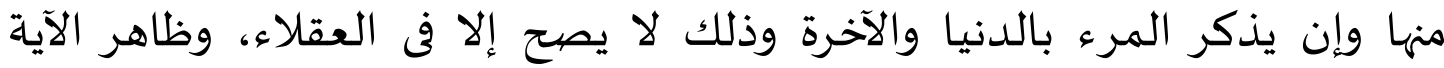

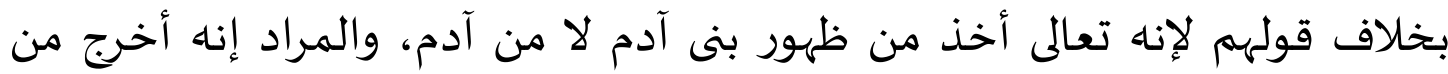

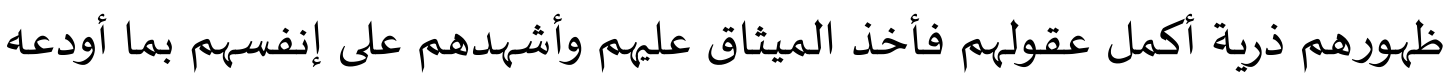

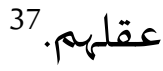

وفى قوله تعالى "ويسبح الرعد بحمده..."38 قال كيف يصح التسبيح من الته

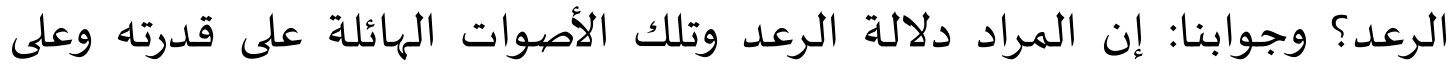

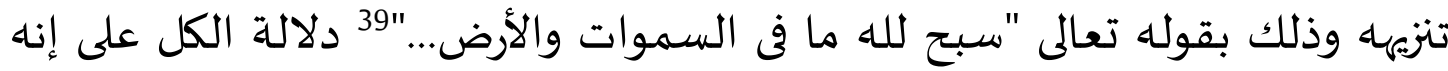

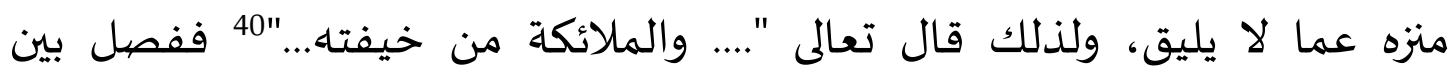

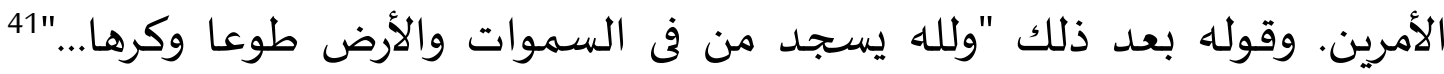

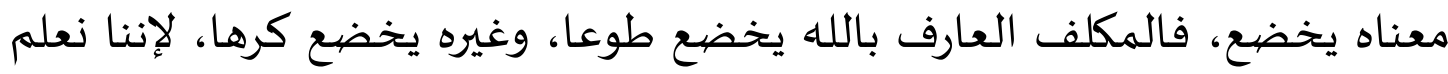
إن نفس السجود لا يقع من كل أحد.

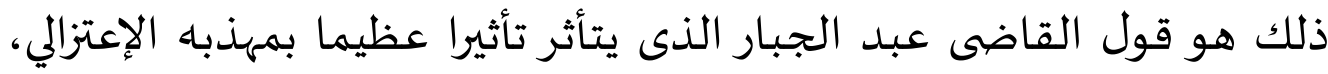

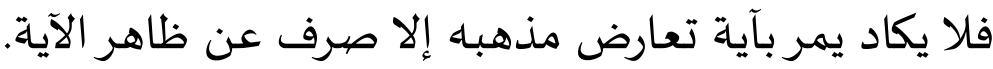

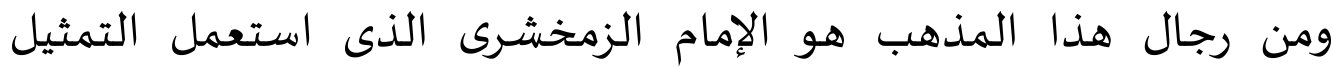

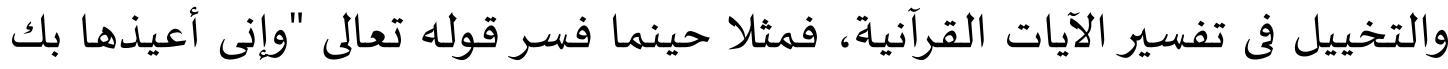
وذرياتها من الشيطإن الرجيم" والشيطإن يمساه من يولد فيستهل صارخا من مس الشيطإن إياه إلإن مريم وابنها.

، لنكة 17 محد حسين الذهبي، التفسير والدفسرون، المجلد الأول؛ دار الكتب الحديث لصاحبها توفيق عفيفي

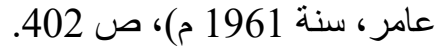

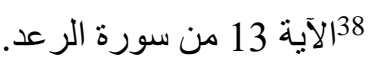
المالآية 1 من سورة الحديد.

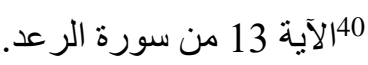

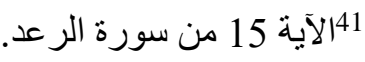

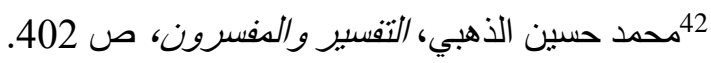
133 - الآية 36 من سورة آل عمر إن. 
فالله أعلم بصحته، فإن صح فمعناه إن كل مولود يطمع الشيطإن فى أغرائه إلا

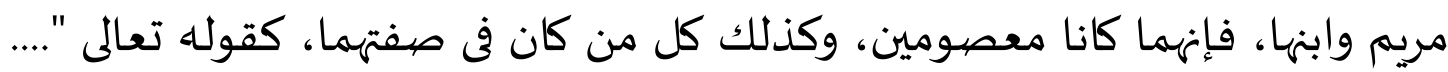

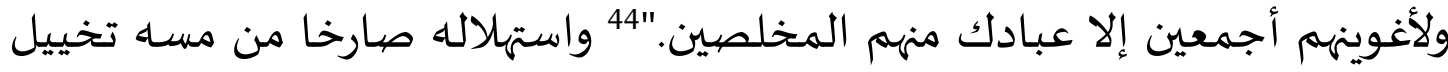

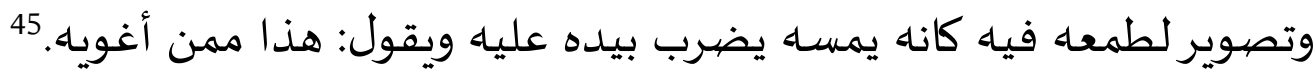

$$
\text { 2- - مجاز القرآن عند الصيوفية. }
$$

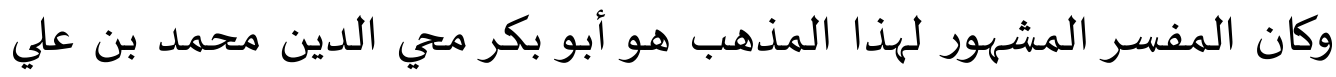

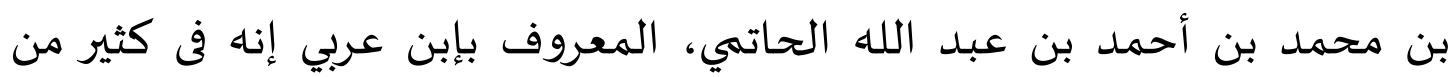
الأحيإن يتعسف فئ التأويل.

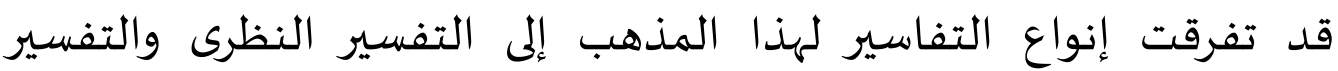
الإشـارى والتفسير الظاهر. وكل هذه الإنواع من التفاسير التأويلية أو المجازية.

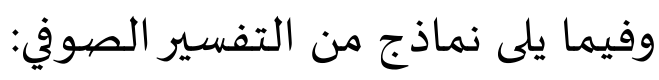

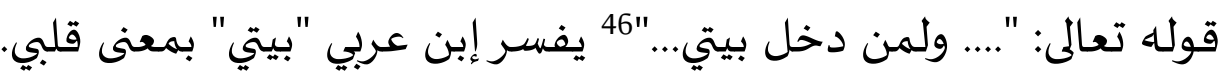

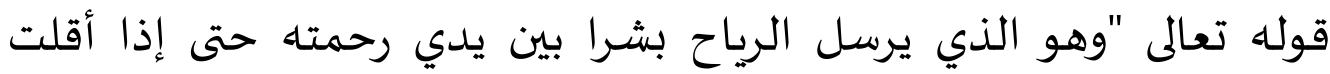

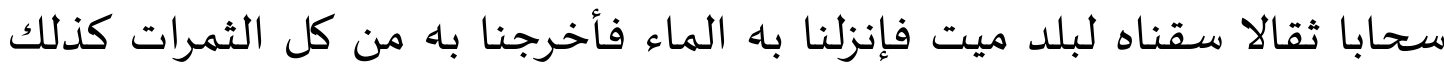

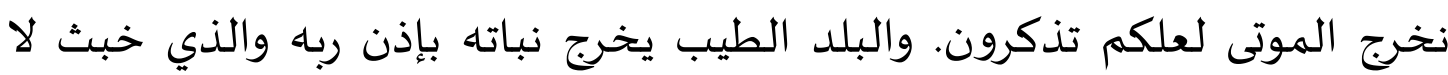

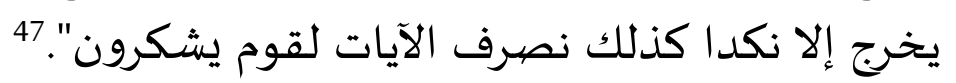

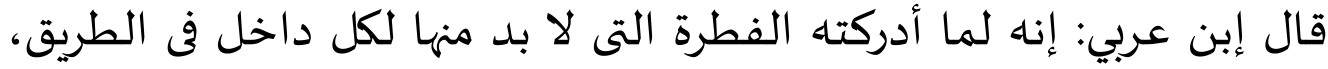

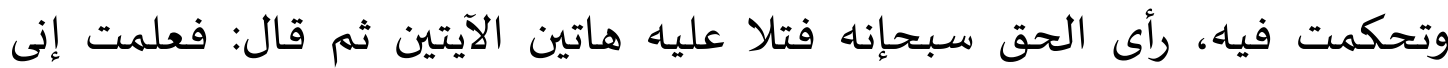

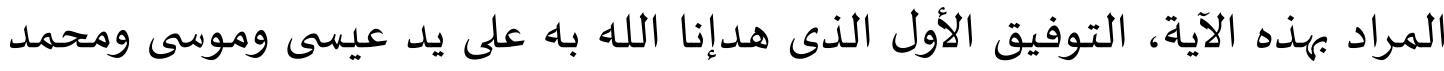

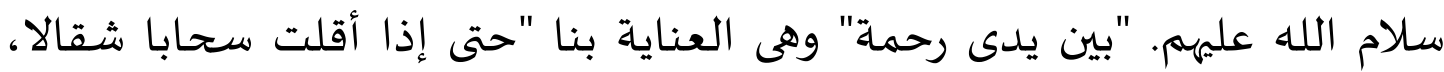

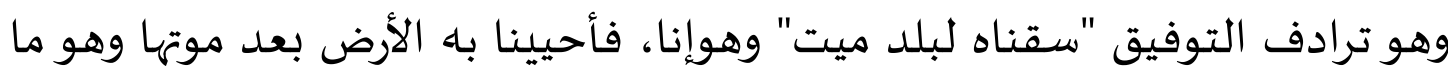

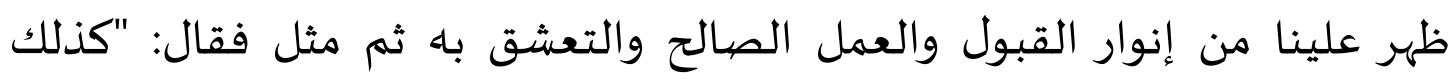

المبالآية 39- 40 من سورة الحجر.

$$
\begin{aligned}
& \text { 45 محمد حسين الذهبي، التفسير والدفسرون، ص } 28 \text { صن } 453 . \\
& \text { الالآية } 28 \text { من سورة نوح. } \\
& \text { 47الآية 57- } 58 \text { من سورة الأعراف. }
\end{aligned}
$$


نخرج الموتى لعلكم تذكرون" يشير بذلك إلى خبر ورد عن النبي صلى الله عليه النهاء

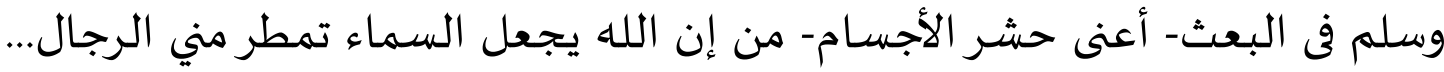

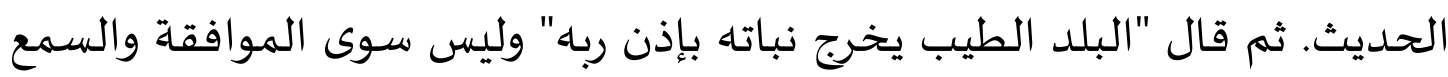

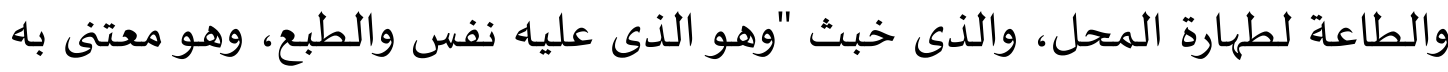

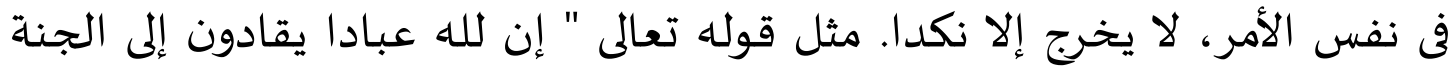

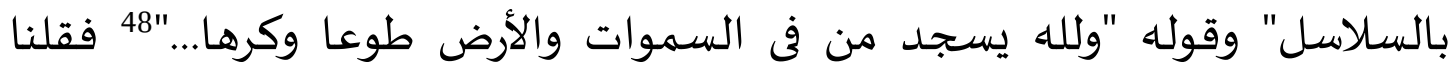
طوعا يا إلهنا.

وقال فى قوله تعالى "ومن يعظم شعائر الله فإنها من تقوى القلوب. لكم فيها منافع إلى أجل مسمى ثم محلها إلى البيت العتيق".

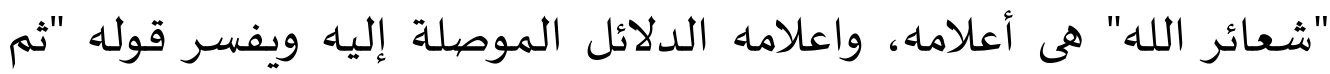

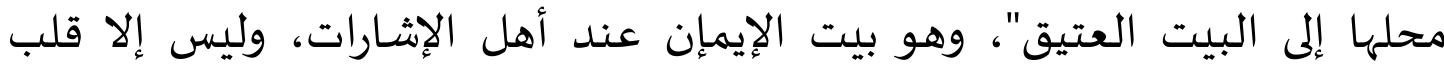
المؤمن الذى وسع عظمة الله وجلاله. 51

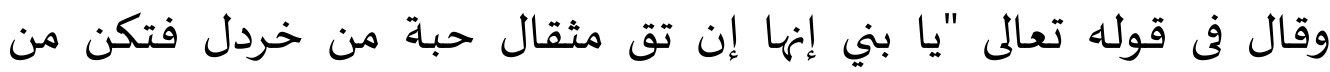

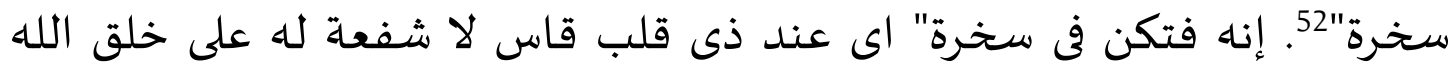

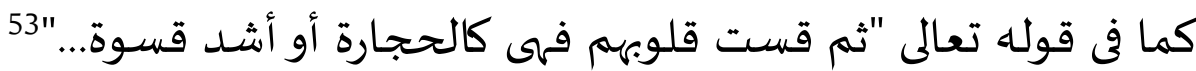
هذا بعض النماذج من التفسير الصوفى الذى يشتمل فئ على فئى كثير من التأويلات.

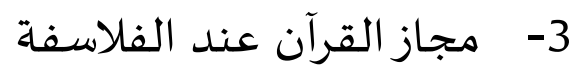

إن الفلاسفة في توفيقهم بين الدين والفلسفة يسيرون الفية على طرية الفيقتين، أولاهما: طريقة التأويل للنصوص الدينية والحقائق الشرعية بما يتفق مع الأراء

$$
\begin{aligned}
& \text { 48 الآية } 15 \text { من سورة الرعد. } \\
& \text { 49 محمد حسين الذهبي، التفسير والمفسرون، صن صد } 80 . \\
& \text { 50الآية 32- } 33 \text { من سورة الحج. } \\
& \text { 51 محمد حسين الذهبي، التفسير والدفسرون، ص } 50 \text { هن } 80 . \\
& \text { 52 5 الآية } 16 \text { من سورة لقمإن. } \\
& \text { 535 - 5 الآية } 74 \text { من سورة البقرة. }
\end{aligned}
$$


الفلسفية، وثإنيتهما: شرح النصوص الدينية والحقائق الشرعية بالأراء والنظريات

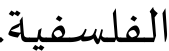

وإليكم نماذج من تفسير هذا المذهب.

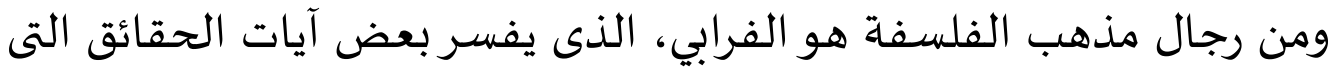

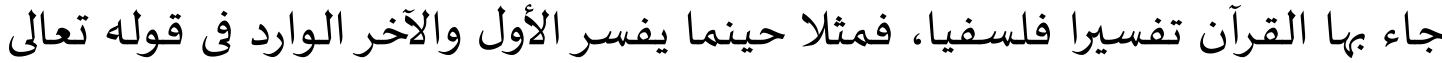

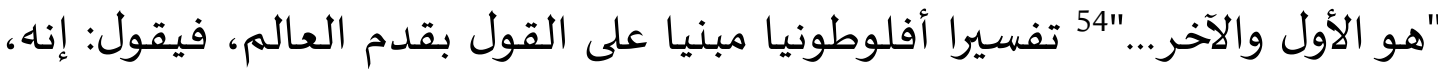

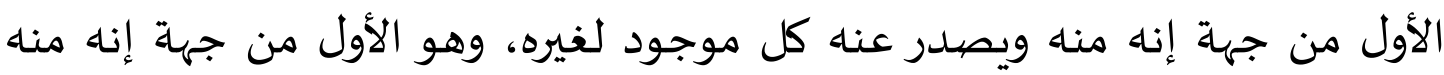

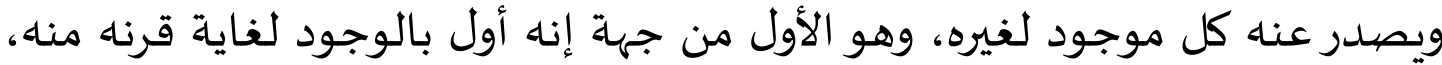

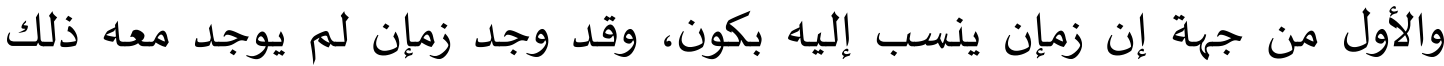
الشيئ ووجد معه لا فيه هو الأول، لإنها إذا اعتبر كل شيئ كان فيانه أولان أثره، وثيانيا

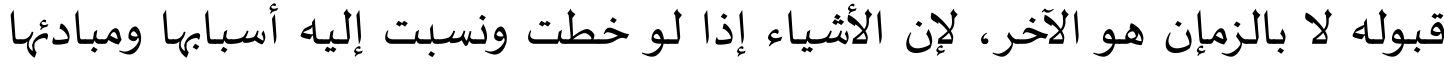

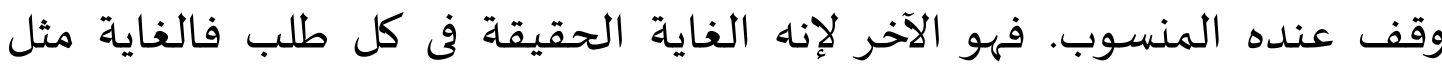

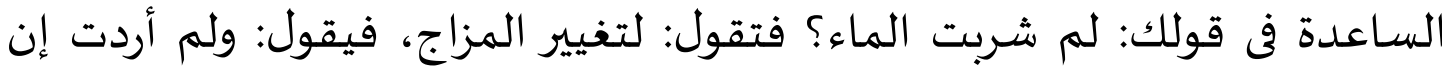

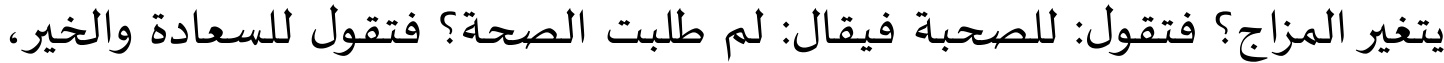

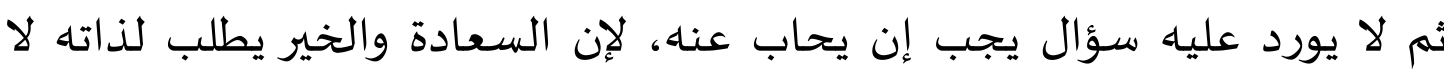
لغيره. فهو المعشوق الأول فلذلك هو آخر كل غاية أول في الفكر آخر في الحصيول، هو الآخر من جهة إن كل زمإن يتأخر عنه، ولا يوجد زمإن النان متأخر عن الحقا..."

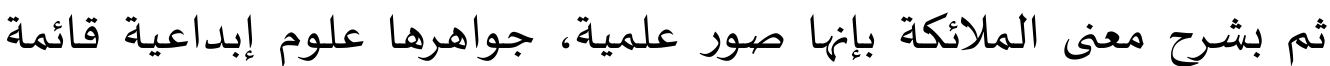

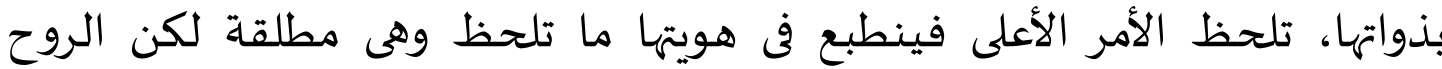
القدسية تخاطبها في اليقظة، والروح البشرية تعاشرها في النوم.

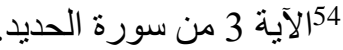

$$
\begin{aligned}
& \text { 55 محد حسين الذهبي، التفسبر والدفسرون، ص } 86 . \\
& \text { 56محد حسين الذهبي، التفسبر والدفسرون، ص } 87 .
\end{aligned}
$$


ونجد الشروح الفلسفية أيضا إخوإن الصفا، إههم يشرحون الجنة والنار بما

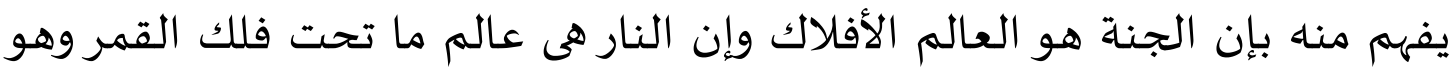

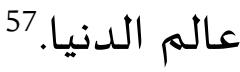

ومن ذلك يفسرون الملائكة بإنها كواكب الأفلاك فيقولون: إن كواكب الفلك

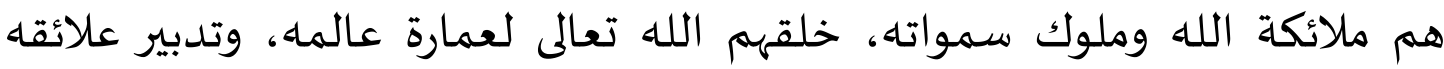

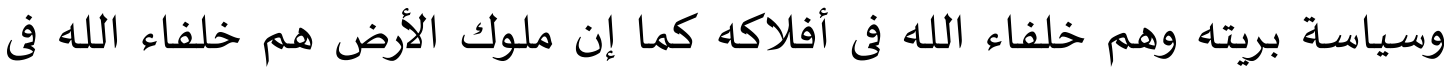

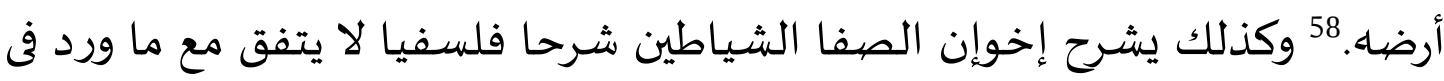

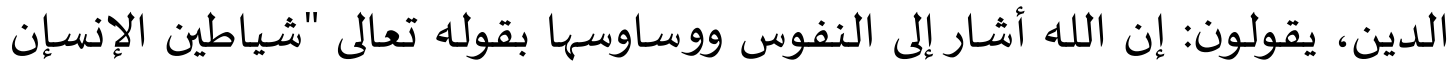

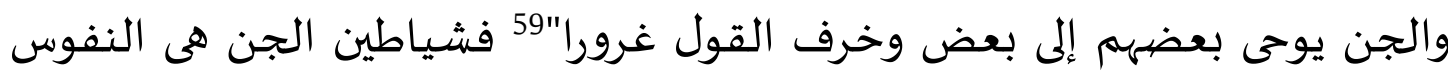

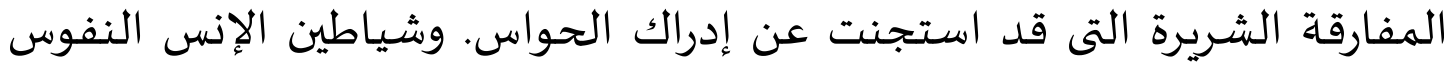
المتجسدة المستإنساة بالأجساد.60

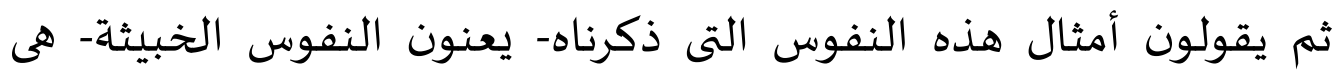
شياطين بالقوة، فإذا فارقت أجسادها كانت شياطين بالنه الفعل.

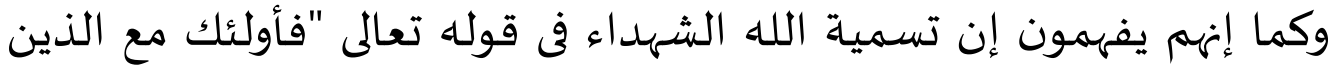

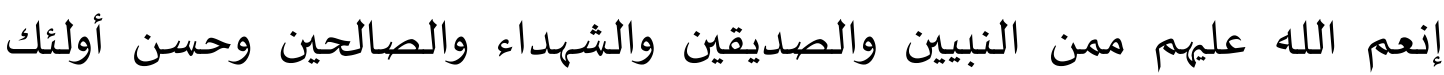

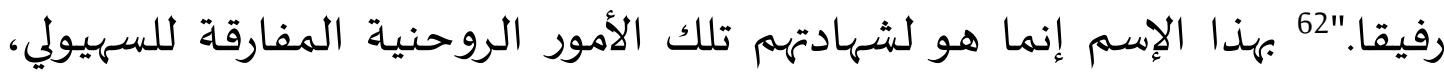
ويعنون بها جنة الدنيا ونعيمها.63 ومن البحوث السابقة وجدنا إن إخوإن الصفا يستعملون المجاز في الهيا

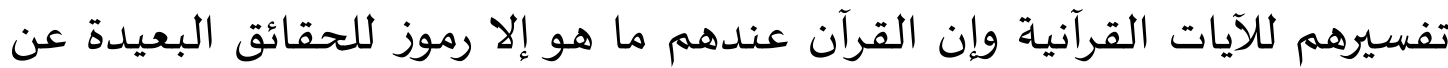

$$
\begin{aligned}
& \text { 57 محمد حسين الذهبي، التفسبر والمفسرون، ص } 87 . \\
& \text { 58 محمد حسين الذهبي، التفسبر والدفسرون، ص } 88 . \\
& \text { 59 الآية } 112 \text { من سورة الإنعام. } \\
& \text { 60محد حسين الذهبي، التفسير والدفسرون، ص } 89 . \\
& \text { 61محمد حسين الذهبي، التفسبر والدفسرون، ص } 89 . \\
& \text { 6262 الآية } 69 \text { من سورة النساء. } \\
& \text { 63محد حسين الذهبي، التفسير والدفسرون، ص } 89 .
\end{aligned}
$$


إذهإن العامة كما في قولهم : إن النبي صلى الله عليه وسلم يخبر خواص أمتاه بما جاء باه واعتقده بالتصريح فى السر والإعلإن غير مرموز ولا مكتوم، ثم يشير إليهما

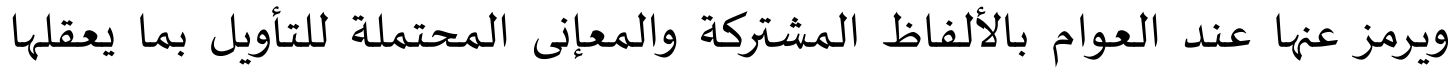
جمهور العلماء وتقبلها نفوسهم.

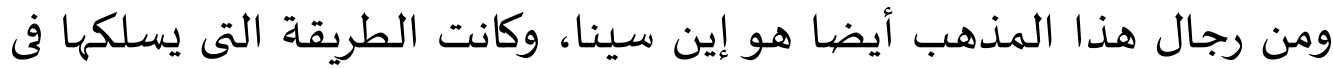

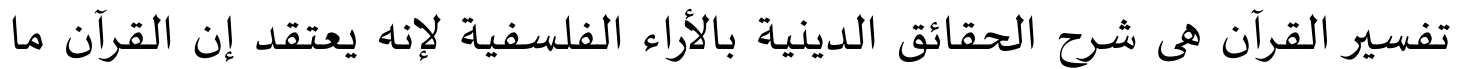

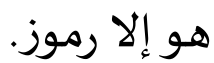

وإليكم بعض أرائه عند تفسير الآيات القرآنية:

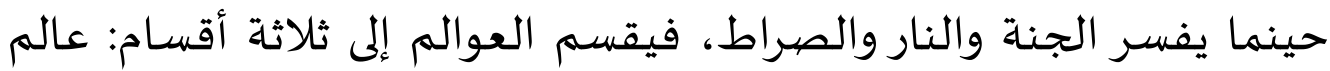

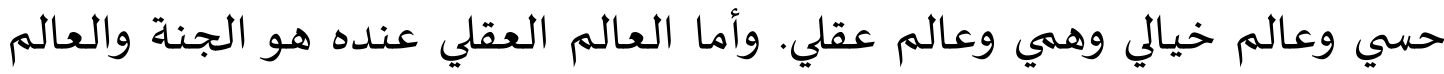

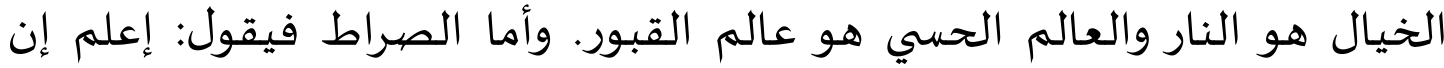

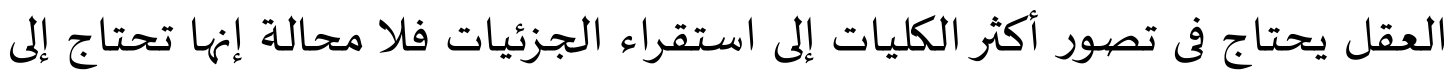

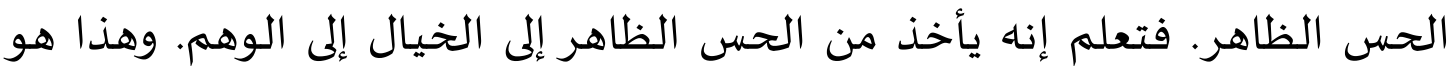

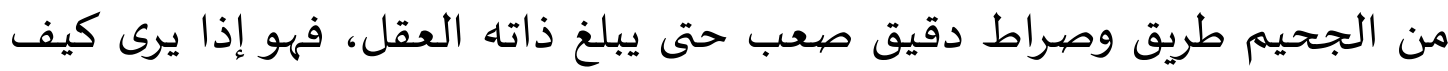

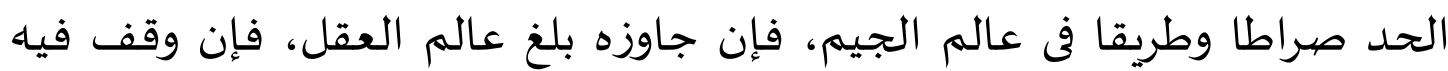
وتخيل الوهم عقلا، وما يشير إليه حق فقد وقف على على الجحيم، وسكن فاون في جهنم وهلك وخسر خسرإنا مبينا.64

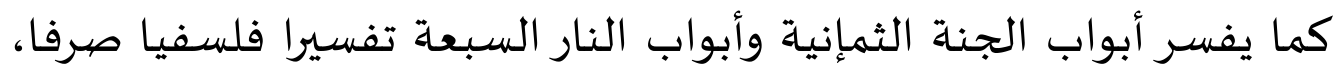

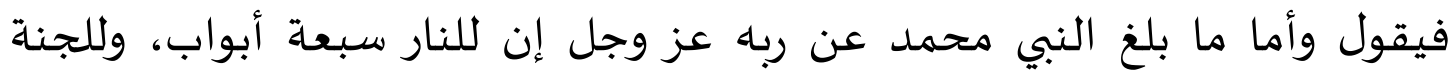

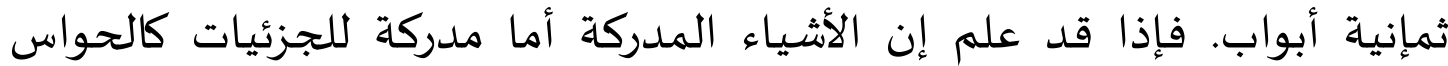

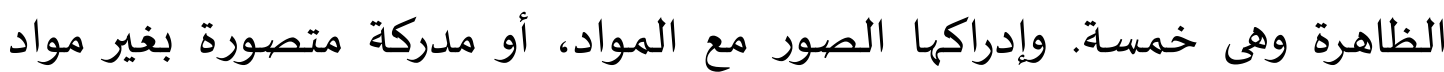

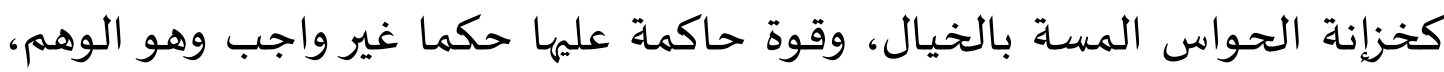

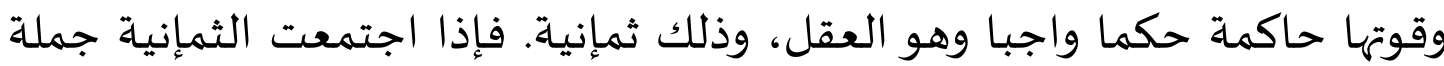

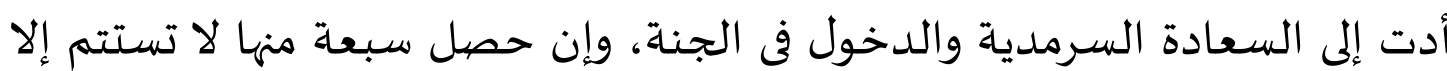

$$
\text { 64 } 60 \text { حمد حسين الذهبي، التفسير والدفسرون، ص } 93 .
$$


بالثامن أدت الشقاوة السرمدية. والمستعمل فى اللغات إن الشيئ المؤدى إلى الشيئ

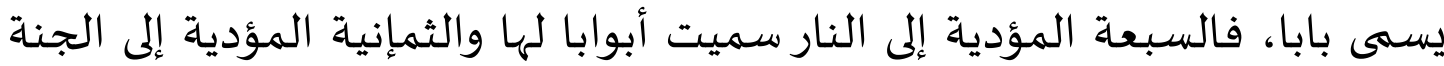

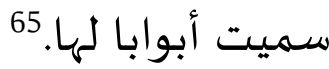
هذه النماذج من التفاسير المجازية للفلاسفة.

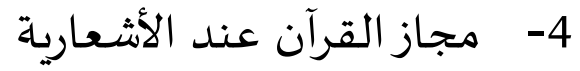

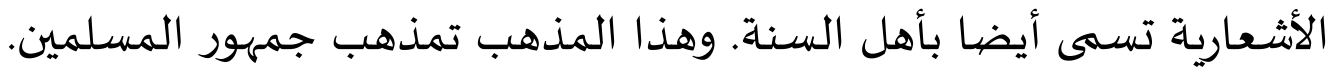

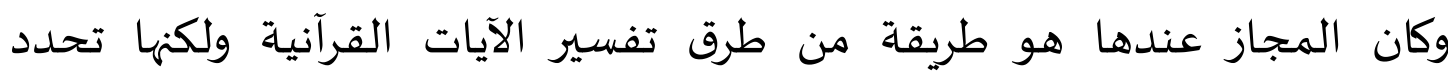

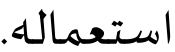

فإذا استبعد المجاز أبدا فسنجد المشكلات عند تفسير الآيات التى تصور

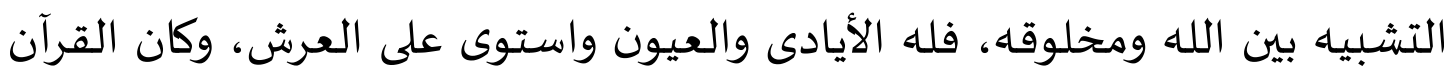

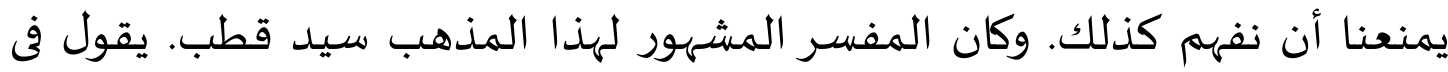

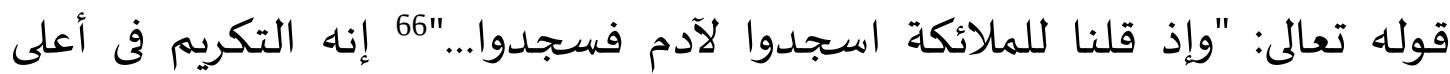

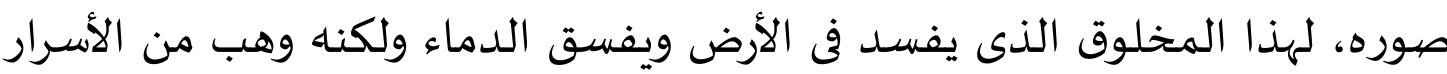

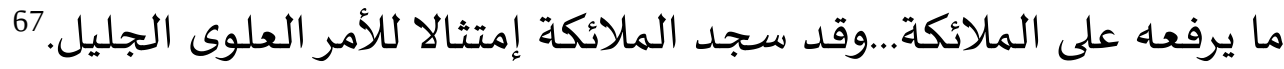
وقد استعمل المجاز عند بعض الآيات فحين يفسر سيد قطب قوله تعالى الى

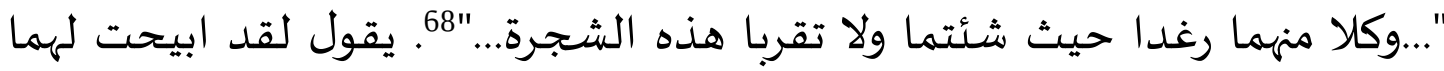

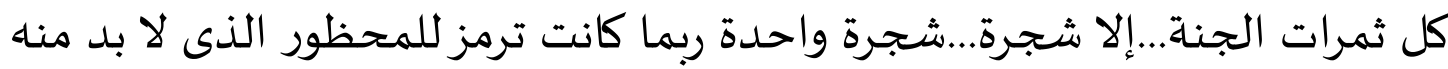
في حياة الأرض.69 تمرات الجنة وهناك اراء إنكرت وقوع المجاز في القرآن، يقول ابن حزم-أحد رجال المذهب الظاهر-فى كتابه المحلى عن القرآن: 65 محمد حسين الذهبي، التفسير والدفسرون، ص 94.

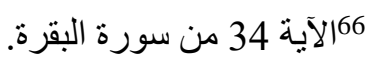
157 سيد قطب، فى ظلال القر إن، المجلد الأول، جده دار العلم للطابعة والنثر ، سنة 1406 هـ - 1986 م،

68 - 5 الآية 35 من سورة البقرة. 69 6سيد قطب، فى ظلال القر إن، المجلد الأول، جده دار العلم للطابعة والنشر، سنة 1406 هـ - 1986 م. 


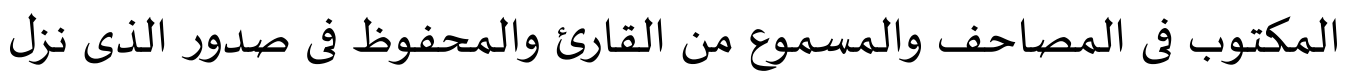

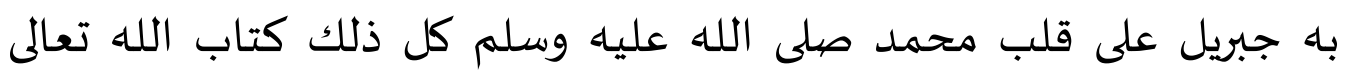
وكلامه القرآن حقيقة لا مجازا.... ثم يقول: ولا يحل لأحد إن يصرف كلان كلام الله تعالى وكلام رسول اللام الله صلى الله

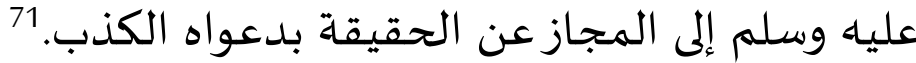

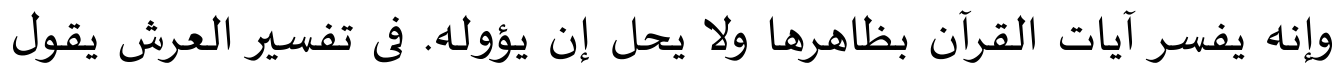

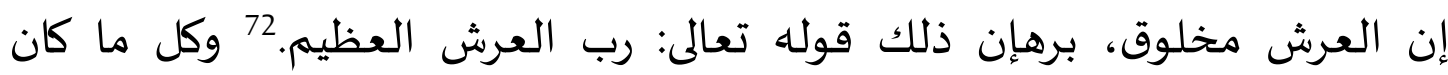

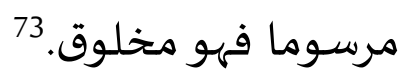

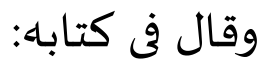
وإن الله تعالى يراه المسلمون يوم القيامة بقوة غير هذه القوة، قال عزوجاهل

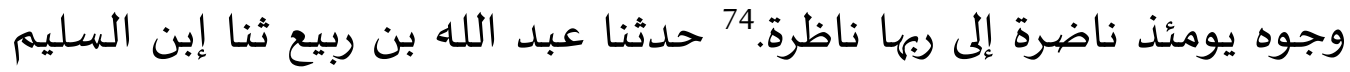

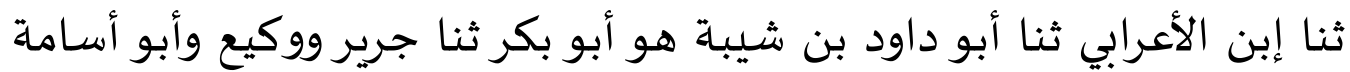

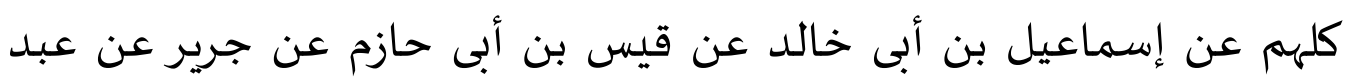

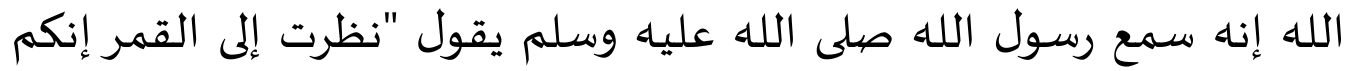

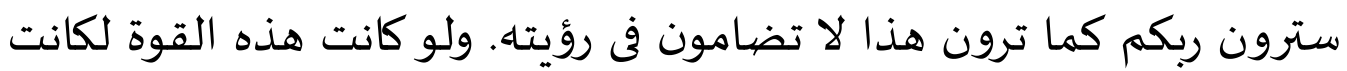
لا تقع إلا على الألوإن. فلذلك، هو يرى إن التفسير بالمجاز لآيات القرآن باطل.

د. - م. إهتمام العلماء بدراسة المجاز

$$
\begin{aligned}
& \text { 707ابن محمد على بن أحمد بن سعيد بن حزم، الدحلي، دار الفكر، الجزء الأول، صص } 32 .
\end{aligned}
$$

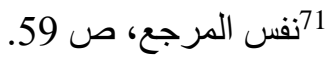

$$
\begin{aligned}
& \text { الآلآية } 129 \text { من سورة النوبة. } \\
& \text { 733 إبن حزم، المرحع السابق، صن صن } 7 .
\end{aligned}
$$

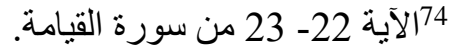

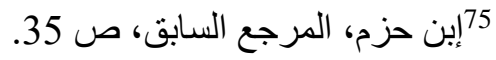


لم نعرف تماما عن التفسير المجازي في عصر رسول الله صلى الله عليه

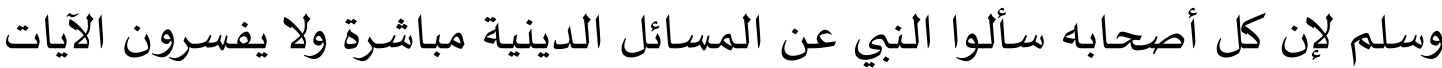

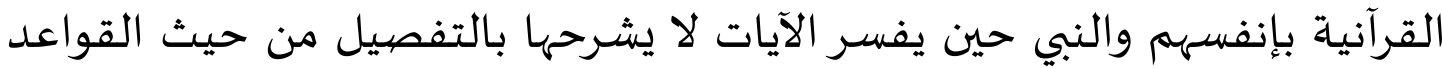

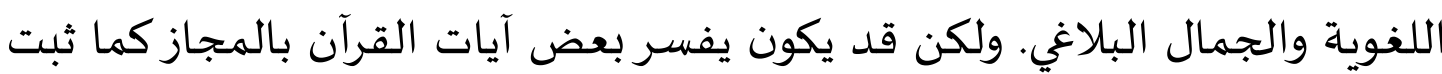

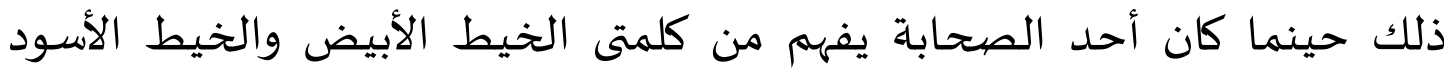
بمعناهما الحقيقى.

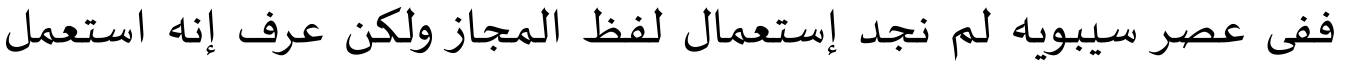
لفظ التعبير الذى نطلق عليه باسم المجاز، إنه إتساع الكلام. في كتابه يقول:

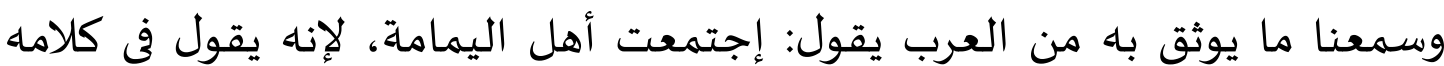
إجتمعت اليمامة يعنى أهل اليمامة، فإنث الفعل في اللفظ لليمامة فترك اللفان اللفظ على ما يكون علياه في سعة الكلام. ويقول في قوله تعالى "واسأل القرية"77 إنما يريد أهل القرية فاخدية فاختصر وعمل الفعل في القرية كما كان عاملا في الأهل.

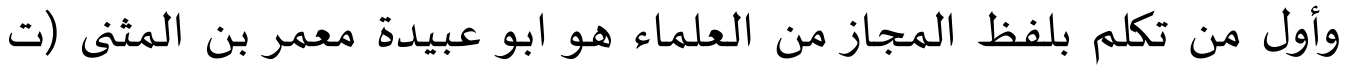

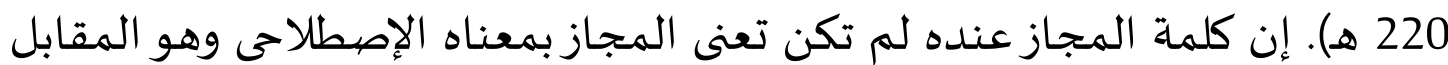

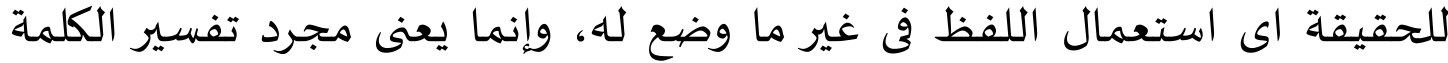

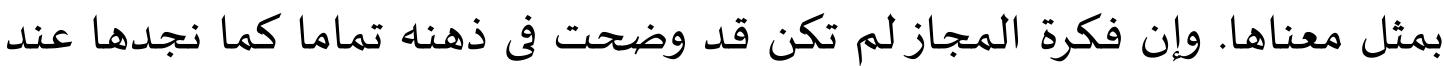
المتأخرين.

يقول في قوله تعالى: "فإذا استويت إنت ومن معك على الفلك."80 مجازه إذها إذا علوت على السفينة وفى قوله تعالى: الرحمن على العرش استوبت إنتوى". 81 إنه بمعنى علا. 176 الدكتور عبد القادر حسين، أثر النحاة فى البحث البلاغي (مصر : دار نهضة للطبع و النشر، 1970 م)

$$
\begin{aligned}
& \text { 177 الآية } 82 \text { من سورة يوسف. } \\
& \text { 78الدكتور عبد القادر حسين، الثر النحاة، المرجع السابق، ص } 119 . \\
& \text { 19 تفس المرجع، ص } 102 . \\
& \text { 80 - الآية } 28 \text { من سورة المؤمنون. }
\end{aligned}
$$


وفى قوله تعالى: "وشجرة تخرج من طور سيناء تنبت بالدهن". 82 مجازه تنبت الدهن والباء زائدة. وفى قوله تعالى: "فإن خفتهم ألا تعدلوا".

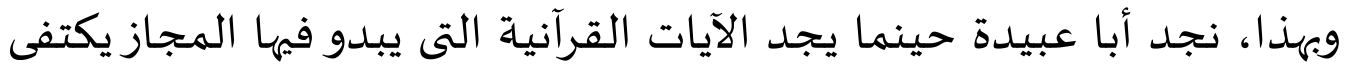

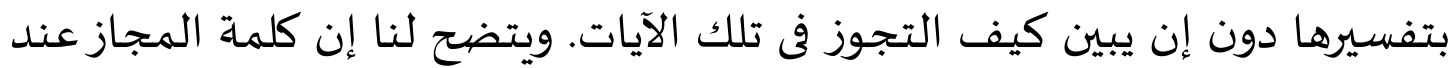

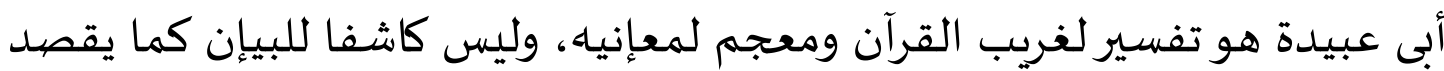

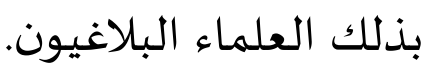

وقد تطور معنى المجاز عند الجاحظ (ت 255 هـ) وهو إن المجاز عنده كان

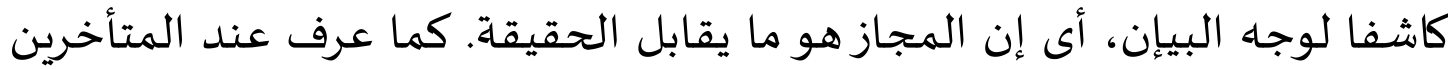

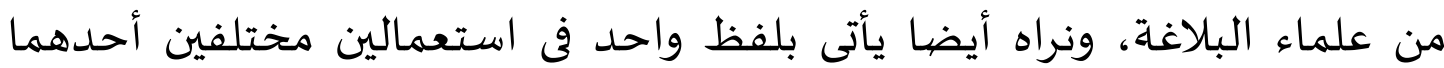

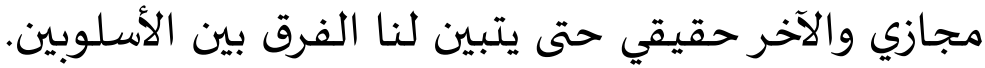

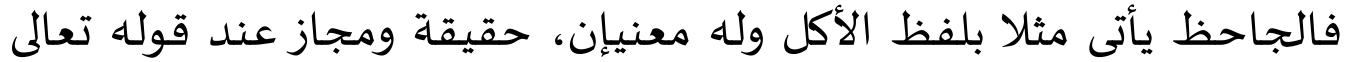

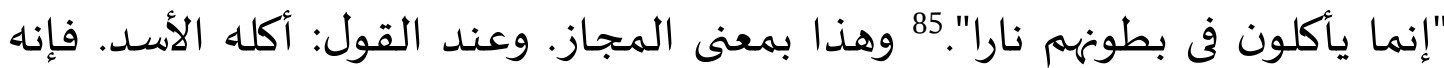

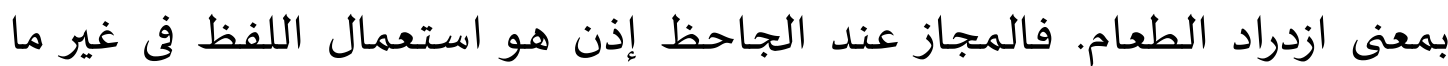
وضع لله ثقة بفهم السـامع عن المتكلم. ومعنى المجاز عند إبن قتيبة هو طرق القول المتهم وأخذه. للحقيقة. يقول في قوله تعالى للسماء والأرض: "...ائتيا طوعا او كرها قالتا: آتينا

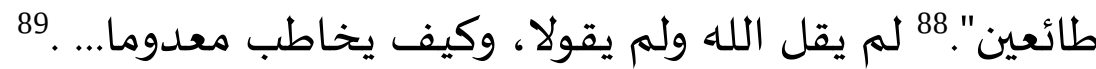

81 - مالآية 28 من سورة طـه. 82 الآية 20 من سورة المؤمنون. 83 - الآية 3 من سورة النساء. 84الدكتور عبد القادر حسين، القرإن والصور البيإنبة، دار نهضة مصر للطبع و النشر الفجالة، القاهرة،

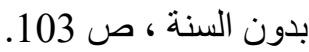
85 الآية 10 من سورة النساء.

$$
\begin{aligned}
& \text { 86 الدكتور عبد القادر حسين، القرابن، المرجع السابق، ص صدرة } 105 .
\end{aligned}
$$

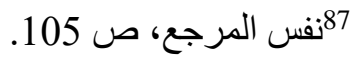

$$
\begin{aligned}
& \text { 88الآية } 11 \text { من سورة فصلت. }
\end{aligned}
$$


وقال إبن قتيبة لمن يزعم إن المجاز فى القرآن من ألوإن الكذب، فهذا من وإن

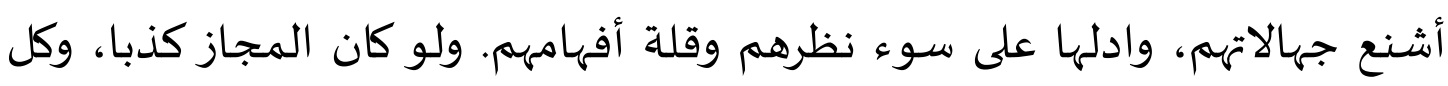

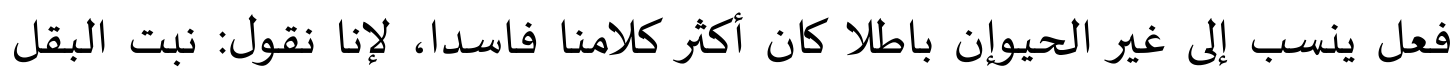

وطالت الشجرة، وأينعت الثمرة.

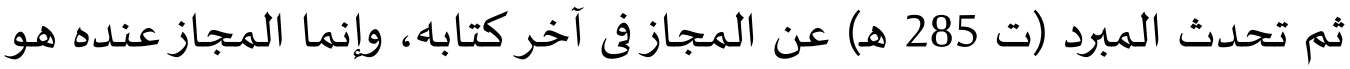

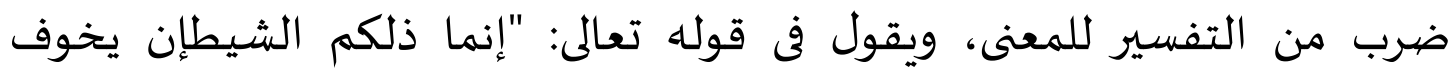

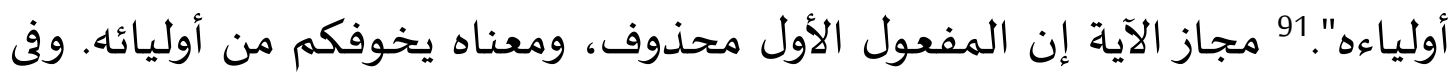

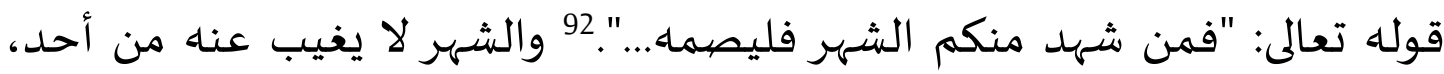

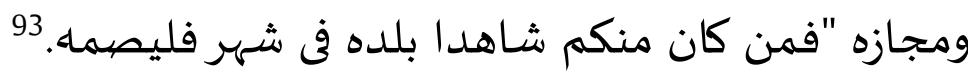

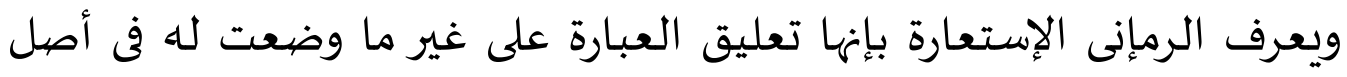

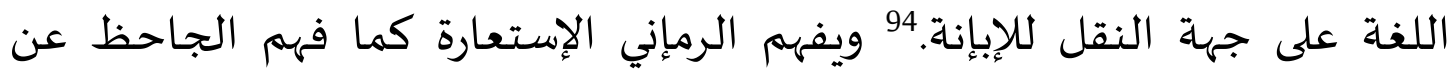

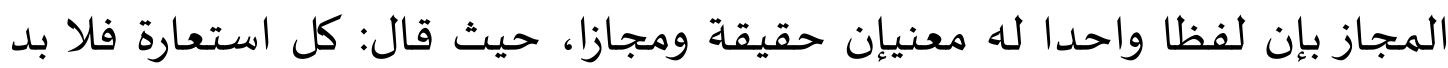
لها من حقيقة وهى أصل الدلالة على المعنى.

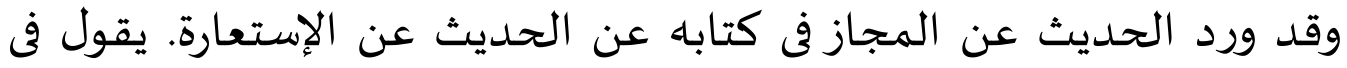

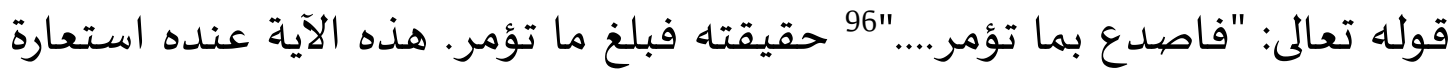

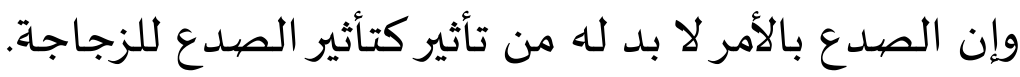

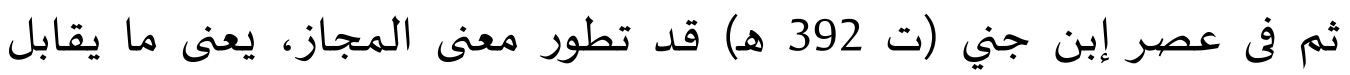

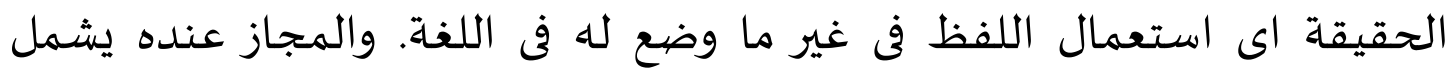

$$
\begin{aligned}
& \text { 89الدكتور عبد القادر حسين، القرإن، المرجع السابق، ص } 106 . \\
& \text { 90 نفس المرجع، ص ص } 107 . \\
& \text { 919الآية } 175 \text { من سورة آل عمر إن. } \\
& \text { 92 الآية } 185 \text { من سورة البقرة. }
\end{aligned}
$$

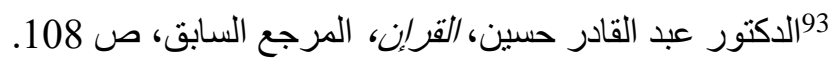

$$
\begin{aligned}
& \text { 94الدكتور عبد القادر حسين، أثر النحاة، المرجع السابق، صل صدران، } 250 .
\end{aligned}
$$

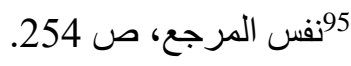

$$
\begin{aligned}
& \text { 96 الآية } 94 \text { من سورة الحجر. }
\end{aligned}
$$


التشبيه البليخ والإستعارة والمجاز المرسل. والمعنى الحقيقي له ثلاثة معإن وهى

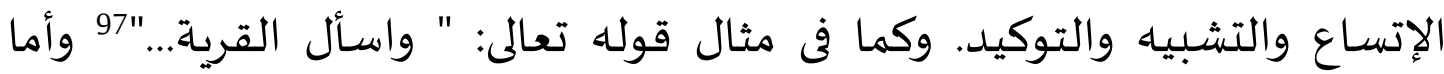

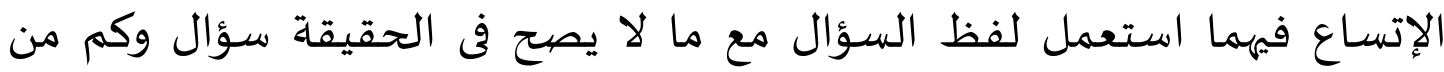

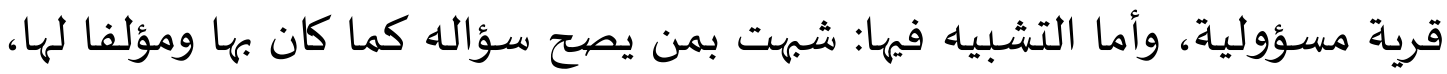

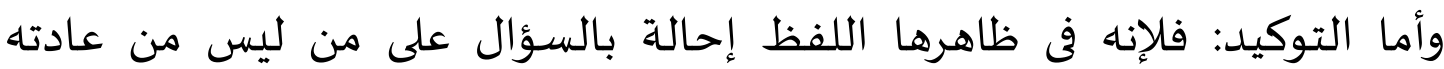

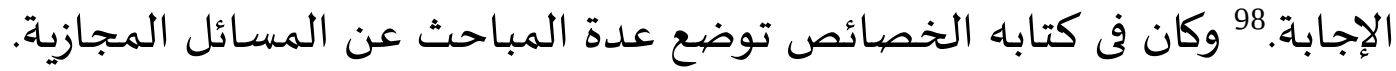

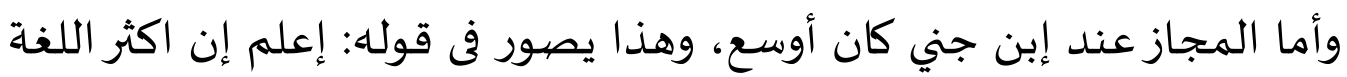

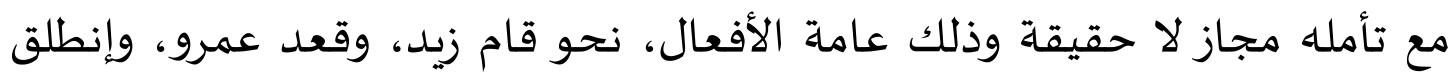

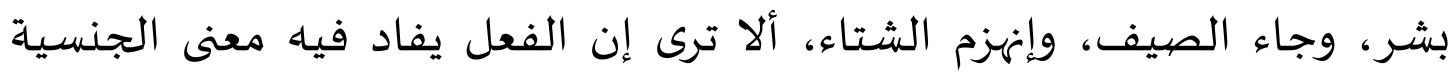

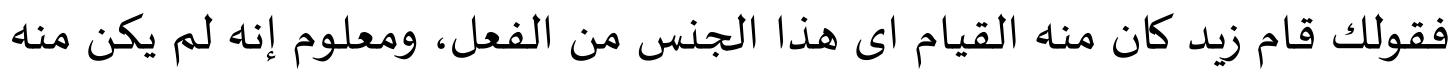

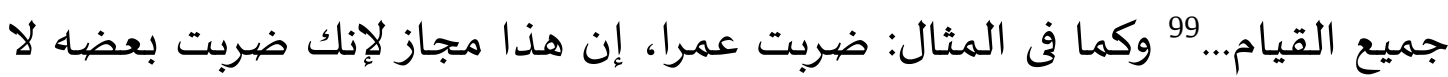

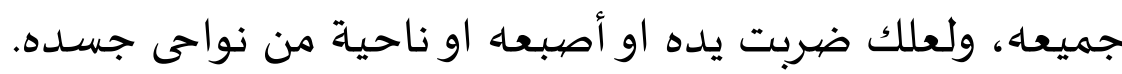

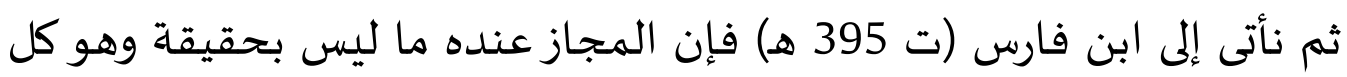

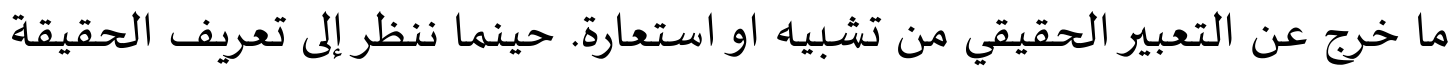

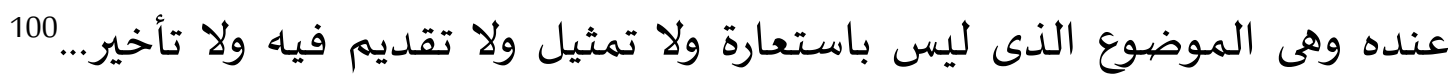

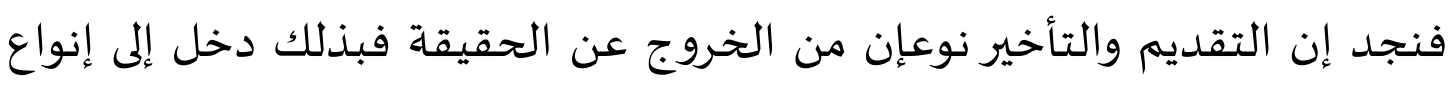
المجاز.

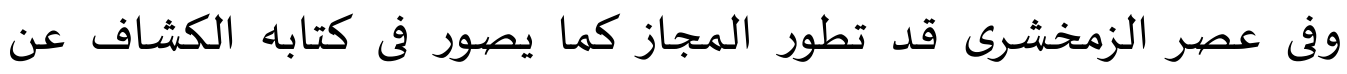

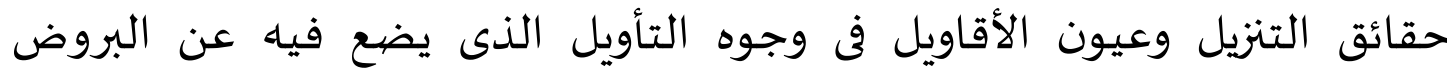

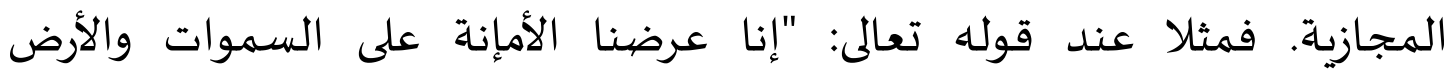

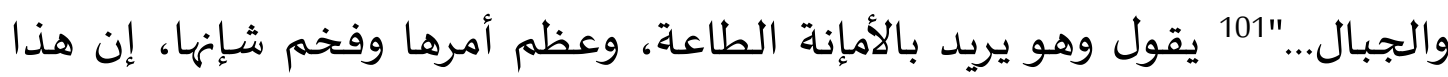

$$
\begin{aligned}
& \text { الآية } 82 \text { من سورة يوسف. } \\
& \text { 98 الدكتور عبد القادر حسين، القراين، المرجع السابق، ص صد } 1107 . \\
& \text { 99نفس المرجع، ص صن } 113 .
\end{aligned}
$$

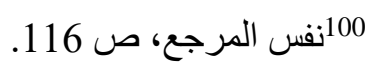

$$
\begin{aligned}
& \text { 101 101الية } 72 \text { من سورة الأحزاب. }
\end{aligned}
$$


الأجرام العظام من السموات والأرض والجبال، وقد إنقدت لأمر الله عز وعلا

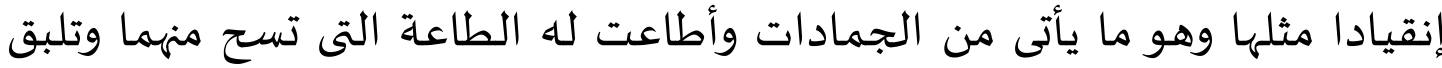

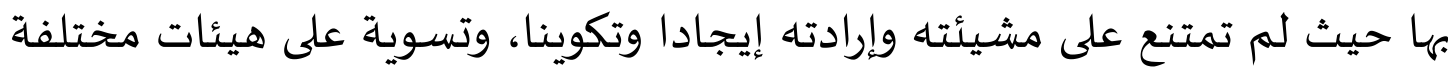
وأشكال متنوعة. 102

وكتابه الكشاف ينقل عنه الألوسي وأبو السعود والنسفي وغيرهم من

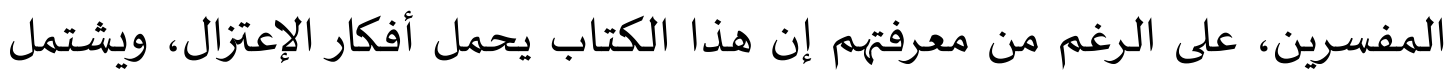
كثيرا من المجازوكثرة استعمال الرأي والعقل.

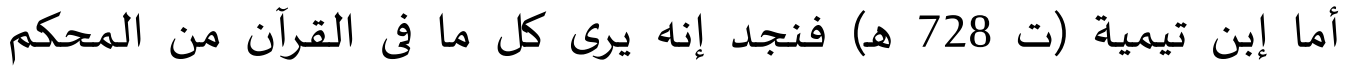
والمتشابه يجب إن نتدبره، ودليل ذلك قوله تعالى: "كتاب إنزلناه إليك مبارك

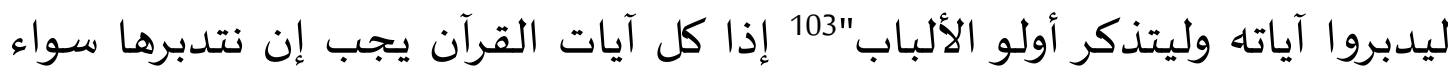

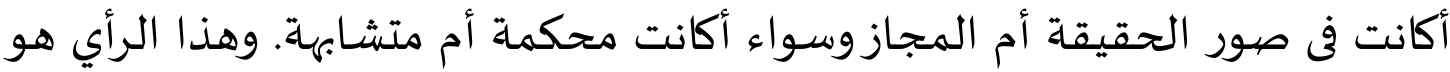
السائد بين جمهور علماء أهل السنة والأشعرية.

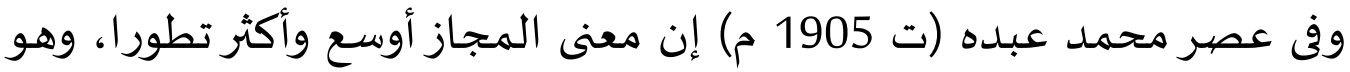
يصور في تفسير عن بعض الآيات القرآنية ذهب إلى استعمال معنى التمثيل كالآية

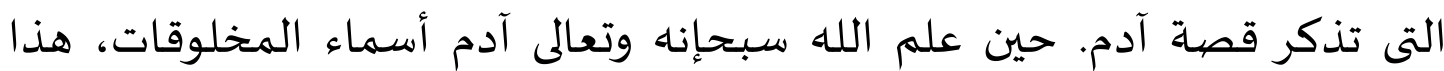

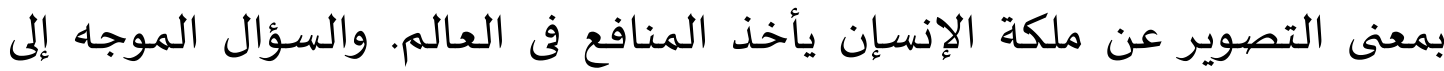

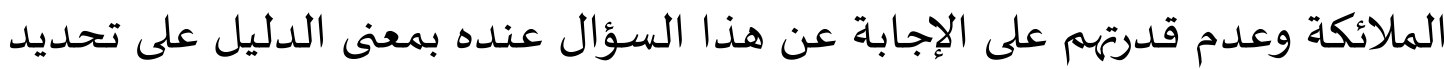

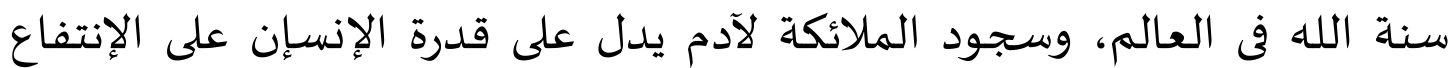
بسنة الله في العالم. وتثاقل الإبليس ليسجد لآدم بمعنى الدليل على ضعف لإلى لإلى

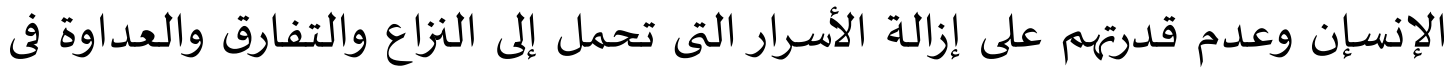

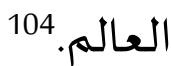

$$
\begin{aligned}
& \text { 102 محمد حسين الذهبي، المرجع السابق، ص } 382 . \\
& \text { 103 الآية } 29 \text { من سورة صن. }
\end{aligned}
$$

104 السيد رشيد رضا، تفسير القرابن الكريم الثهير بالتفسير الدنار(بيروت-لبنان: دار المعرفة، بدون السنة)، ص 265. 
وأما لفظ الملائكة عنده فله معنيإن: الأول، إن الملائكة هم خلق الله الغائبون ولا نعرف حقائقهم ولكن لا بد من الإيمإن بهم، والثإنى، إناه بمعنى قدرة الإنها

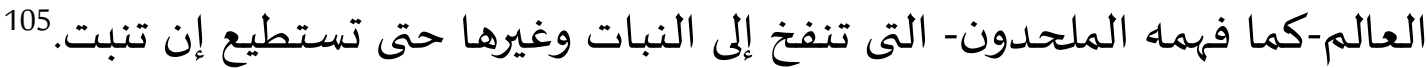

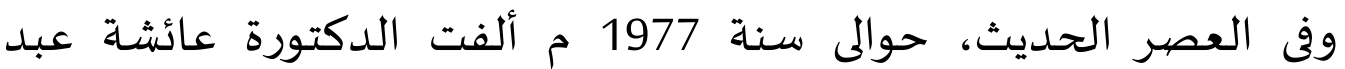

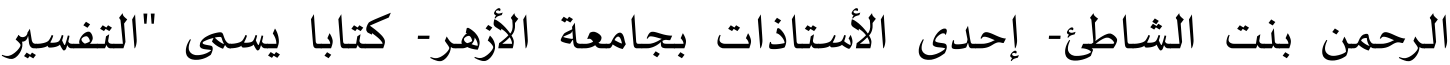

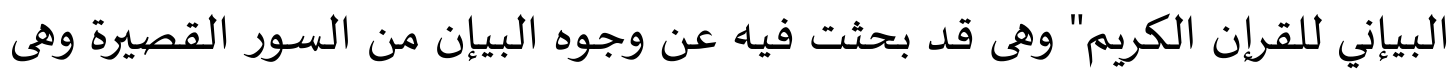

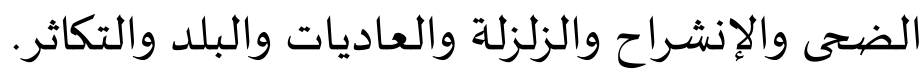
وكما وجدنا أيضا الإختلاف بين العلماء في الألفاظ غير الواضحة في إثباديات

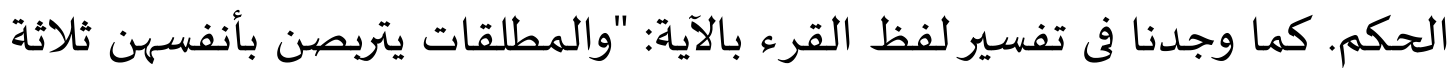
قروء".

والقرء عن اللغة بمعنى الطهور والحيض، فأي المعنيين هو المراد في هذه

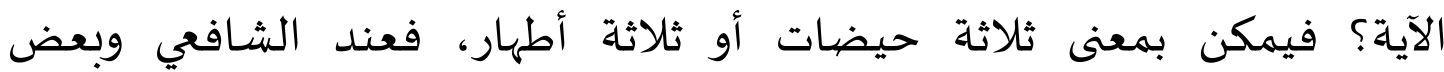

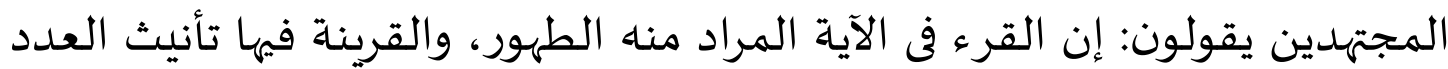

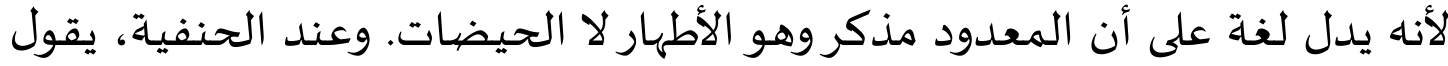

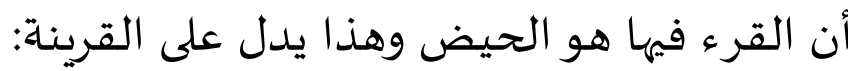

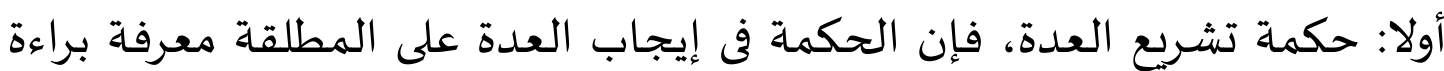
رحمها من الحمل، والذى يعرف هذا هو الحيض لا لا الطهر.

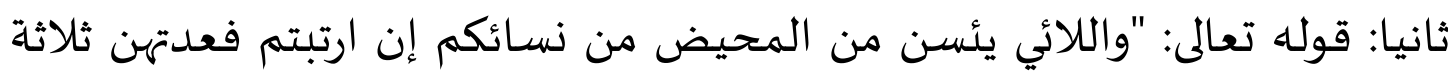

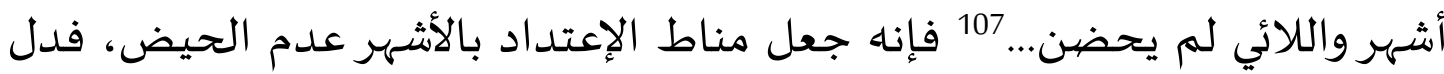
على أن الأصل هو الإعتداد بالحيض. لمهن.

105نفس المرجع، ص 267.

106 الآية 228 من سورة البقرة.

107 الآية 4 من سورة الطلاق. 
ثالثا: قول رسول الله صلى الله عليه وسلم: طلاق الأمة وعدتها حيضتان.

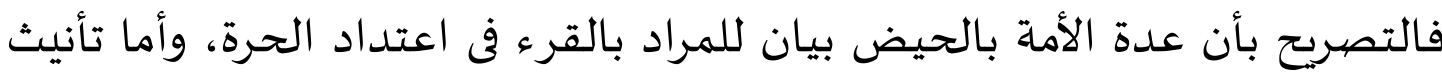

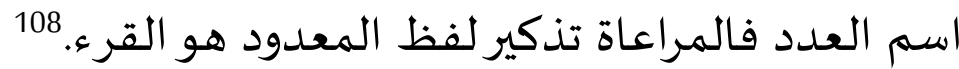

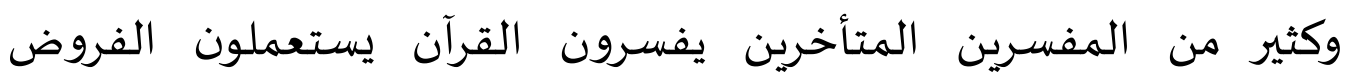
المجازية مثل المراغى وفضل الرحمن وغيرهما.

\section{هـ استخدام المجاز عند المعاصرة وقيمها في فهم التعاليم الدينية}

في هذا البحث تتبين لنا إن إنكار وقوع المجاز في القرآن أمر مستحيل. لإنها بعض آياته لا نعرف إلا بعد معرفة القرآن التى تدل على ذلك. وكلما نتدبر آياته تتفجر من خلالها القيم والحكم البالغة.

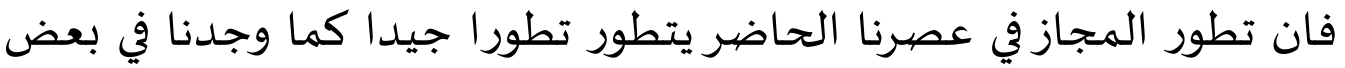

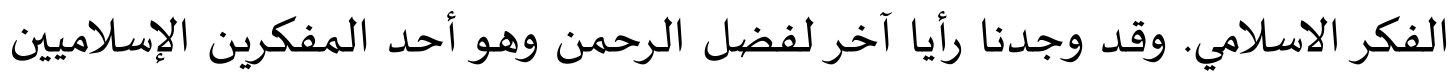

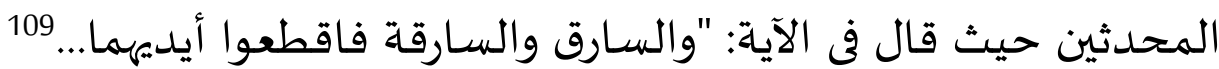

Hukum potong tangan -sangat mengerikan- merupakan tradisi yang lahir di Arab Saudi sebelum adanya Islam jadi bukan hukum Islam. ${ }^{110}$

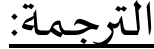

$$
\begin{aligned}
& \text { إن حكم قطع اليد مروع جدا....وهو التقاليد التى ظهرت في العربية السعودية } \\
& \text { قبل ظهور الإسلام فليس من أحكام الإسلام. } \\
& \text { وهو يؤول معنى "فاقطعوا أيديهما" إلى المعنى المجازي الإم بقوله: }
\end{aligned}
$$

Sebagai perintah menghalangi tangan-tangan pencuri untuk mencuri lewat perbaikan ekonomi. ${ }^{111}$

108الثنيخ عبد الوهاب خلاف، علم أصول الفقه (مصر: دار العلم، الطبعة 12، 1398 هـ/1978 م)، ص 173 109 الآية 38 من سورة المائدة.

${ }^{110}$ Taufiq Adnan Amal; Islam dan Tantangan Modernitas (Studi atas Pemikiran Hukum Fazlu al-Rahman) (Bandung: Mizan، 1993 M.)، h. 160. 
الترجمة:

وهو بمثابة أمر لمنع أيدى السارقين عن السرقة عن طريق إصلاح الحياة الإقتصادية.

فالقرينة في هذه اللفظ هي "أيديهما". لفظ اليد بمعني القوة لأن اليد آلة في العمل اذن اقطاع اليد هو اقطاع القوة.

وقد اتفق جمهور العلماء إنه في تفسير المجاز يحتاج القوة إلى القرينة لتؤول

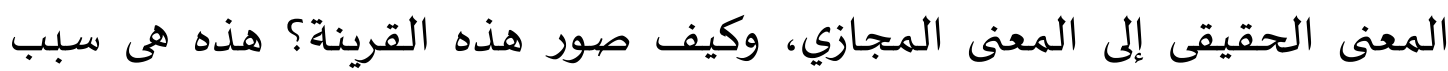

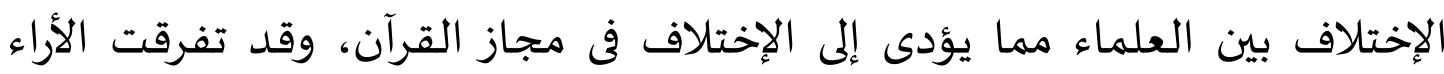

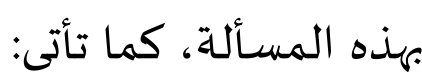

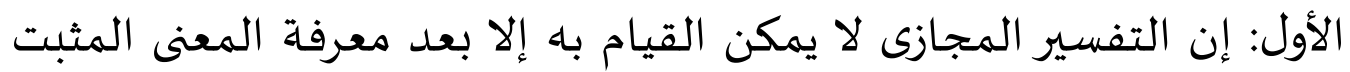

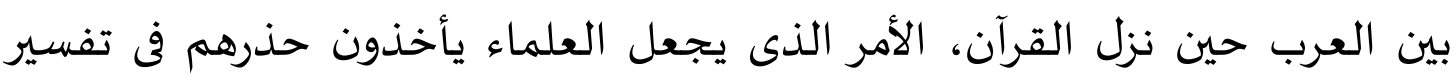

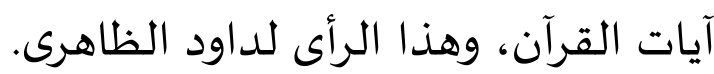

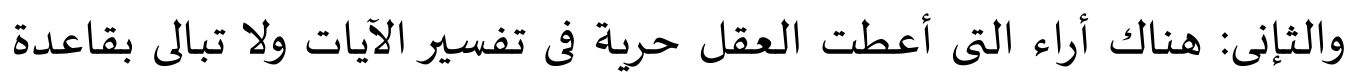

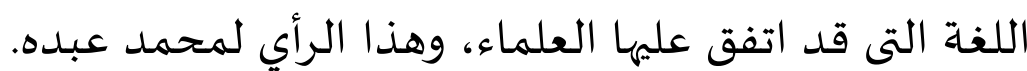

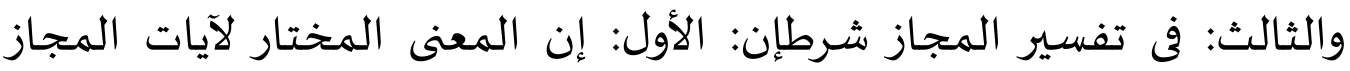

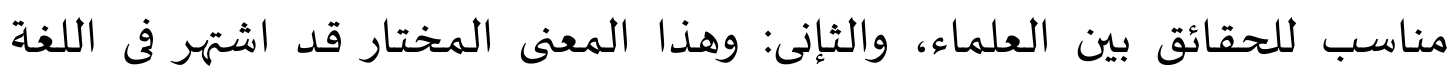
العربية القديمة.

ومن هنا، تتضح لنا القيم في دراسة المجاز ولاسيما في محاولة فهم معإنى

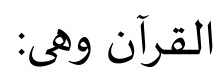

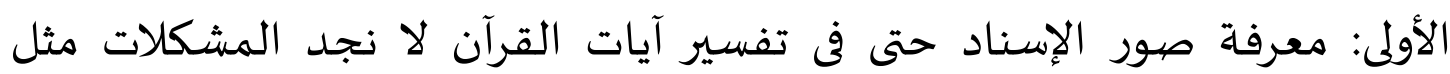

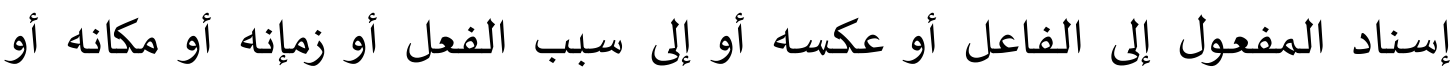
مصيدره. والثإنية: معرفة القرائن التى تدل على الآيات، وشروط القرائن:

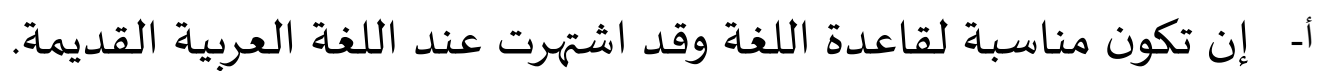

${ }^{111}$ Taufiq Adnan Amal, Islam dan Tantangan Modernitas. h. 160. 
ب- وإن تكون مناسبة لحال الزمإن والمكان. ت- وإنها لا تختلف بسنة الله مناسبة والتعاليم الدينية.

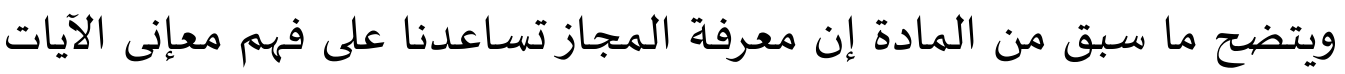
التى لا يمكن إدراكها بمعناها الحقيقي مما يقلل من الإختلاف في تفسير الآيات

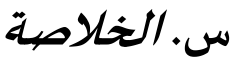

من البيان الذى قد سبق، يستطيع الكاتب أن يعرض الخلاصات وهي لا

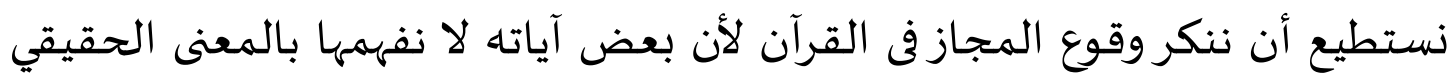

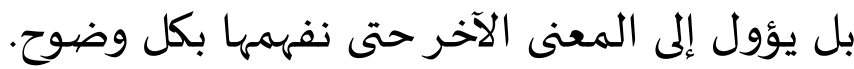

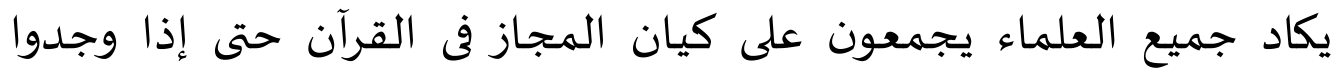

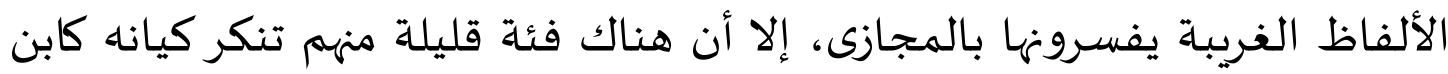

$$
\text { حزم من مذهب الظاهرية. }
$$

قيم المجاز هى معرفة صيور النسبة ومعرفة القرائن التى تدل عليها الآيات

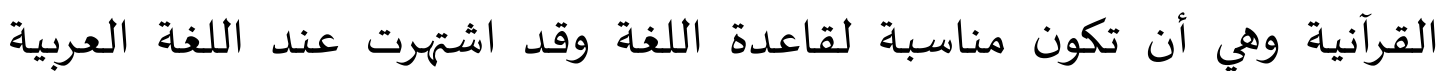

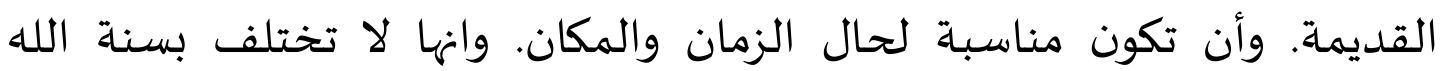
والتعاليم الدينية. إن خير موقف نتخذه إزاء تفسير الآيات القرآنية تقدير الأراء المخالفة لرأينا فلا نعتبر أنفسنا أصحاب الحق والصهواب دون الآخرين. 
Amal, Taufiq Adnan. Islam dan Tantangan Modernitas (Studi atas Pemikiran Hukum Fazlu al-Rahman) Bandung: Mizan, 1993 M.

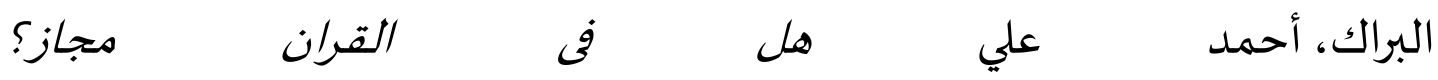
https://vb.tafsir.net/tafsir20214/\#.XNwlIhQzbDc

$11 / 07 / 1431-22 / 06 / 2010$

الجارم، على و مصطفى أمين، البلاغتة الواضحة،، لندن، شركة مكمالإ، الطبعة

الخامسة عشرة، سنة 1961

https:/www.dr- الجراح، رشيد جـلية الحقيقة والمجاز في القران الكريهم rasheed.com/2013/12/blog-post.html

حزم، ابن محمد على بن أحمد بن سعيد بن، المحلي، دار الفكر، الجزء الأول.

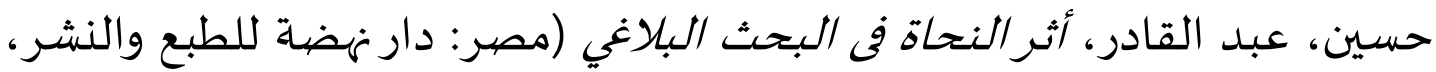
1970

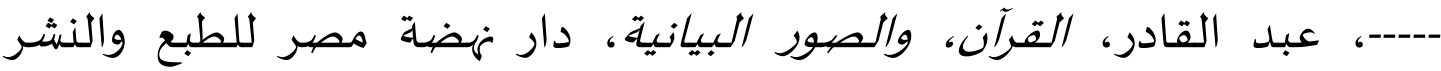

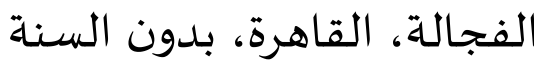

خلاف، الشيخ عبد الوهاب، علم أصهول الفقه (مصر: دار العلم، الطبعة 12788،

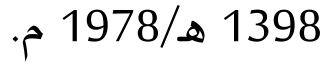

الذهبي، محمد حسين، التفسير والمفسرون، المجلد الأول؛ دار الكتب الحديث لصاحبها توفيق عفيفي عامر، سنة 1961 م.

رضا، السيد رشيد، تفسير القرآن الكريم الشهير بالتفسير المنار(بيروت-لبنان: دار

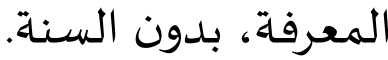

https://twitter.com/saaidnet1/status السكران، إبراهيم بن عمر خلاصة في المجاز 1666309263678177280 
لمرآن

$$
\text { الحرفية }
$$$$
\text { التفسيرات }
$$

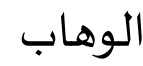$$
\text { عبد }
$$

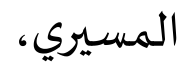

https://www.aljazeera.net/knowledgegate

/opinions/2006

المجاز

محمد

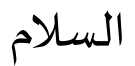

عبد

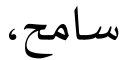

https://www.alukah.net/literature_language/0/74896/

القطان، مناع، مباحث فى علوم القرآن، منشورات العصر الحديث، سنة 1393

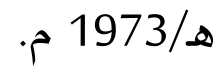

قطب، سيد، في ظلال القرآن، المجلد الأول، جده دار العلم للطابعة والنشر، سنة

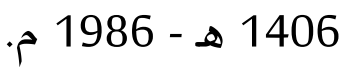




\section{Guidelines}

\section{Submission of Article}

urnal Adabiyah welcomes the articles submission with the main themes on Humanities and Islamic Studies with the emphasis on interdisciplinary and intertextuality approach. Adabiyah is thematicly published twice in a year. ie the theme of the humanities in June and the Islamic Study in December.

Themes related to Islamic Studies are textual studies, scriptural traditions, Islamic law, and theology; and those related to Humanities are language, literature, history, and culture. This scholarly journal Guarantees that the editor decision based on the peer review results will not exceed 30 days from the paper submission date.

Authors are invited to read our archives; to find the relevant topics for the journal, and to submit complete unpublished scientific researches, which are not under review in any other conferences or academic journal.

\section{PUBLICATION ETHIC}

Publication Ethic and Malpractice Statement

Jurnal Adabiyah is a peer-reviewed journal, published twice a year by the Faculty of Adab and Humaniora, Alauddin State Islamic University of Makassar Indonesia. It is available online as open access sources as well as in print. This statement clarifies ethical behaviour of all parties involved in the act of publishing an article in this journal, including the author, the editor-in-chief, the Editorial Board, the reviewers, and the publisher. This statement is based on COPE's Best Practice Guidelines for Journal Editors.

Ethical Guideline for Journal Publication

The publication of an article in Jurnal Adabiyah, is an essential building block in the development of a coherent and respected network of knowledge. It is a direct reflection of the quality of the work of the authors and the institutions that support them. Peer-reviewed articles support and embody the scientific methods. It is therefore important to agree upon standards of expected ethical behavior for all parties involved in the act of publishing: the author, the editor, the reviewer, the publisher, and the society. As the publisher of Jurnal Adabiyah, the Faculty of Adab and Humaniora takes its duties of guardianship over all stages of publishing seriously and it recognizes its ethical and other responsibilities. The Faculty of Adab and Humaniora committed to ensuring that advertising, reprint or other commercial revenue has no impact or influence on editorial decisions.

\section{Publication Decisions}

The editors of Jurnal Adabiyah is responsible for deciding which articles submitted to the journal should be published. The validation of the work in question and its importance to researchers and readers must always drive such decisions. The editors may be guided by the policies of the journal's editorial board and constrained by such legal requirements as shall then be in force regarding libel, copyright infringement, and plagiarism. The editors may confer with other editors or reviewers in making their decisions.

\section{Plagiarism Screening}

It is basically author's duty to only submit a manuscript that is free from plagiarism and academically malpractices. The editor, however, will check all submitted papers through Turnitin.

\section{Fair Play}

An editor at any time evaluates manuscripts for their intellectual content without regard to race, gender, sexual orientation, religious belief, ethnic origin, citizenship, or political philosophy of the authors. 


\section{Confidentiality}

The editors and any editorial staff must not disclose any information about a submitted manuscript to anyone other than the corresponding author, reviewers, potential reviewers, other editorial advisers, and the publisher, as appropriate.

\section{Disclosure and Conflicts of Interest}

Unpublished materials disclosed in a submitted manuscript must not be used in editors' own research without the express written consent of the author.

\section{DUTIES OF AUTHORS}

\section{Reporting Standards}

Authors of reports of original research should present an accurate account of the work performed as well as an objective discussion of its significance. Underlying data should be represented accurately in the paper. A paper should contain sufficient detail and references to permit others to replicate the work. Fraudulent or knowingly inaccurate statements constitute unethical behaviour and are unacceptable.

\section{Originality and Plagiarism}

The authors should ensure that they have written entirely original works, and if the authors have used the work and/or words of others that this has been appropriately cited or quoted.

\section{Multiple, Redundant, or Concurrent Publication}

An author should not in general publish manuscripts describing essentially the same research in more than one journal or primary publication. Submitting the same manuscript to more than one journal concurrently constitutes unethical publishing behaviour and is unacceptable.

\section{Acknowledgement of Sources}

Proper acknowledgment of the work of others must always be given. Authors should cite publications that have been influential in determining the nature of the reported work.

\section{Authorship of the Paper}

Authorship should be limited to those who have made a significant contribution to the conception, design, execution, or interpretation of the reported research. All those who have made significant contributions should be listed as co-authors. Where there are others who have participated in certain substantive aspects of the research project, they should be acknowledged or listed as contributors. The corresponding author should ensure that all appropriate co-authors and no inappropriate co-authors are included on the paper, and that all co-authors have seen and approved the final version of the paper and have agreed to its submission for publication.

\section{Disclosure and Conflicts of Interest}

All authors should disclose in their manuscript any financial or other substantive conflict of interest that might be construed to influence the results or interpretation of their manuscript. All sources of financial support for the project should be disclosed.

\section{Fundamental errors in Published Works}

When an author discovers a significant error or inaccuracy in his/her own published work, it is the author's obligation to promptly notify the journal editor or publisher and cooperate with the editor to retract or correct the paper.

\section{PLAGIARISMI}

It is basically author's duty to only submit a manuscript that is free from plagiarism and academically malpractices. The editor, however, will check all submitted papers through Turnitin. 


\section{AUTHOR GUIDELINES}

\section{Guidelines for online submission:}

1. Author should first register as Author to the website of Jurnal Adabiyah. Click the menu "register" to register as an author.

2. Once after the author is registered, please login to the website of Jurnal Adabiyah and submit the article through online submission (with the stat us of active submissions).

3. The article should follow the standard template of Jurnal Adabiyah provided in the website.

4. The citation and bibliography should follow the Turabian citation style.

5. Author is restricted not to send his/her article to another journal before having confirmation from the editorial team (approximately 4 weeks right after the article submitted).

6. Author should follow editorial decisions and recommendations related to the article completion. All reviews and assessements will be informed through online submission.

Article submitted to Jurnal Adabiyah editorial board must follow these guidelines:

1. Article should be based on the scientific research in the field humanities and Islamic studies;

2. Article must be an original work and has not been previously published;

3. Article should be written in Arabic or English languages;

4. Article must be typed in one-half spaced on A4-paper size;

5. Article's length is about $6,000-10,000$ words;

6. All submission must include a 150-250 word abstract;

7. Abstract should be written in 3 languages; Arabic, English, and Bahasa;

8. Full name(s) of the author(s) must be stated, along with his/her/their institution and complete address;

9. All submission should be in OpenOffice, Microsoft Word, RTF, or WordPerfect document file format;

10. Bibliographical reference must be noted in footnote and bibliography according to Jurnal Adabiyah style. In addition, it is suggested for author(s) to use reference manager tools such as 30 MENDELEY or 2 otero

When a source is cited for the first time, full information is provided: full name(s) of author(s), title of the source in italic, place of publication, publishing company, date of publication, and the precise page that is cited. For the following citations of the same source, list the author's last name, two or three words of the title, and the specific page number(s). The word ibid., op.cit., and loc.cit. are may not be used any more.

\section{Example in footnotes:}

${ }^{1}$ Mircea Eliade (ed.), The Encyclopedia of Religion, vol. 8 (New York: Simon and Schuster, 1995), h. 18.

${ }^{2}$ Norman Daniel, Islam and the West (Oxford: One World Publications, 1991), h. 190.

${ }^{3}$ Syeikh Ja'far Subhānī, Mafăhim Al-Qur'ān (Beirut: Mu'assasah Al-Tarikh Al-'Arabī, 2010)., Juz 5, h. 231. 
${ }^{4}$ Syeikh Ja'far Subhānī, Mafăhim Al-Qur'ān, h. 8-9.

\section{Example in bibliography:}

Subhānī, Syeikh Ja'far. Mafāhim Al-Qur'ān. Beirut: Mu'assasah Al-Tarikh Al-'Arabī, 2010.

Eliade, Mircea (ed.). The Encyclopedia of Religion, vol. 8. New York: Simon and Schuster, 1995.

Daniel, Norman. Islam and the West. Oxford: One World Publications, 1991.

Shihab, Muhammad Quraish. Sunnah-Syiah Bergandengan Tangan: Mungkinkah? Kajian Atas Konsep Ajaran Dan Pemikiran. Cet. III. Jakarta: Lentera Hati, 2007.

Detail informations of the footnotes:

1. Holy book

Al-Qur'ân, Al-Baqarah/2: 185.

Perjanjian Baru, Mrk. 2: 18.

2. Qur'anic translation

${ }^{1}$ Departemen Agama RI, al-Qur'an dan Terjemahannya (Jakarta: Darus Sunnah, 2005), h. 55.

3. Book

${ }^{1}$ Muḥammad 'Ajjaj al-Khațib, Ușl al-Hadith: 'Ulumuh wa Mușțalaḥuh (Beirut: Dâr al-Fikr, 1989), h. 57.

4. Translation Books

${ }^{1}$ Toshihiko Izutsu, Relasi Tuhan dan Manusia: Pendekatan Semantik terhadap al-Qur'an, terj. Agus Fahri Husein dkk (Yogyakarta: Tiara Wacana, 2003), h. 14.

5. Voluminous book

${ }^{1}$ Muḥammad al-Ṭâhir b. 'Ashur, al-Tạnn̄̄r wa al-Tanwīr, Vol. 25 (Tunisia: Dâr al-Suhûn, 2009), h. 76.

${ }^{1}$ Muḥammad b. Ismā‘īl al-Bukharī, al-Jami` al-Ṣahịḥ, Vol. 2 (Beirut: Dar al-Kutub al-‘Ilmìyah, 1999), h. 77.

6. Article in book

${ }^{1}$ Sahiron Syamsuddin, "Metode Intratekstualitas Muhammad Shahrur dalam Penafsiran al-Qur'an" dalam Abdul Mustaqim dan Sahiron Syamsuddin (eds.), Studi al-Qur'an Kontemporer: Wacana Baru Berbagai Metodologi Tafsir (Yogyakarta: Tiara Wacana, 2002), h. 139.

7. Article in encyclopaedia

${ }^{1}$ M. Th. Houtsma, "Kufr” dalam A. J. Wensinck, at al. (ed.), First Encyclopaedia of Islam, Vol. 6 (Leiden: E.J. Brill, 1987), h. 244.

8. Article in journal

${ }^{1}$ Muhammad Adlin Sila, "The Festivity of Maulid Nabi in Cikoang, South Sulawesi: Between Remembering and Exaggerating the Spirit of Prophet", Studia Islamika 8, no. 3 (2001): h. 9.

9. Article in mass media

${ }^{1}$ Masdar F. Mas'udi, "Hubungan Agama dan Negara", Kompas, 7 Agustus 2002. 
10. Article in Internet

${ }^{1}$ Muhammad Shahrūr, "Reading the Religious Teks: a New Approach" dalam http://www.shahrour.org/25 Februari 2010/diakses 5 Juni 2010.

11. Thesis or dissertation

${ }^{1}$ Syahruddin Usman, "KinerjaGuru Penddikan Agama Islam pada SMAN dan SMKN Kota Makassar”, Disertasi (Makassar: PPs UIN Alauddin, 2010), h. 200.

\section{COPYRIGHT NOTICE}

Authors who publish with this journal agree to the following terms:

1) Authors retain copyright and grant the journal right of first publication with the work simultaneously licensed under a Creative Commons Attribution License that allows others to share the work with an acknowledgement of the work's authorship and initial publication in this journal.

2) Authors are able to enter into separate, additional contractual arrangements for the non-exclusive distribution of the journal's published version of the work (e.g., post it to an institutional repository or publish it in a book), with an acknowledgement of its initial publication in this journal.

3)Authors are permitted and encouraged to post their work online (e.g., in institutional repositories or on their website) prior to and during the submission process, as it can lead to productive exchanges, as well as earlier and greater citation of published work (See The Effect of Open Access). 